\title{
The role of emergent processing technologies in tailoring plant protein functionality: New insights
}

\author{
Zita Avelar ${ }^{\mathrm{a}, *}$, António A. Vicente ${ }^{\mathrm{a}}$, Jorge A. Saraiva ${ }^{\mathrm{b}}$, Rui M. Rodrigues ${ }^{\mathrm{a}}$ \\ ${ }^{\text {a }}$ CEB - Centre of Biological Engineering, University of Minho, Campus de Gualtar, 4710-057 Braga, Portugal \\ ${ }^{\mathrm{b}}$ LAQV@REQUIMTE-Associated Laboratory for Green Chemistry, Department of Chemistry, University of Aveiro, 3810-193 Aveiro, Portugal
}

\section{A R T I C L E I N F O}

\section{Keywords:}

Ohmic heating

High pressure processing

Plant protein

Structural changes

Functionalization

\begin{abstract}
A B S T R A C T
Background: Plant proteins possess promising technological-functional properties that can be used for the development of innovative protein systems. Following the global requirements of environmentally friendly politics, "green" and cost-effective processing technologies, such as ohmic heating and high pressure processing are of great interest. These technologies have demonstrated their potential to modify protein structure and therefore their function, opening interesting possibilities for the design of functional food systems. However, these innovations must also include nutritional and health/wellness aspects, such as the interaction with other food components, and the behavior in the gastrointestinal tract (digestibility and bioavailability).

Scope and approach: This review addresses the most promising technological-functional attributes of plant proteins, as well as considerations and strategies needed for the development of innovative food systems. New insights will also be provided on how emerging processing technologies such as ohmic heating and high pressure processing can affect the behavior of proteins. The processing effects in proteins' structure and in their technological-functional properties and ultimately in the biofunctional and nutritional aspects of foods made therefrom will be critically discussed.

Key findings and conclusions: Fundamental research regarding the relationship between structural modifications and functionality of more conventional proteins is still required. Furthermore, additional research is necessary on proteins from less studied sources, highlighting those displaying both functional and quality parameters of interest. Emergent processing technologies can help guaranteeing the quality and preservation of foods, as well as act as effective tools to develop technological-functional attributes of food proteins ensuring nutritional and health/wellness aspects.
\end{abstract}

\section{Introduction}

Due to economic development and urbanization in developed countries, the consumption of animal protein has reached levels that exceed the standard nutritional needs. A quite different scenario occurs in undeveloped countries where animal protein sources are scarce and protein-energy malnutrition is a serious concern (Kumar, 2016; Neacsu, McBey, \& Johnstone, 2017). The world demand for the main sources of animal protein (in the form of meat, dairy and fish products) is expected to double by 2050 , despite all the negative environmental, ethical, and public health impacts associated with their production and consumption (Neacsu et al., 2017). This, coupled with the continuous growth of the population which is expected to exceed 9 billion people by 2050, will lead to a continuous increase in the demand for food proteins that could only be met by the consumption of novel and sustainable protein sources (Pojić, Mišan, \& Tiwari, 2018; Worldometers, 2020). The demand for sustainable alternatives to animal protein sources led to a growing interest in plant-based proteins. The cultivation of such protein sources is considered less damaging to the environment comparing to the exploitation of animal protein, so they represent a more sustainable choice (Poore \& Nemecek, 2018; Wu et al., 2014).

Plant proteins can be found in numerous sources, being distinguished mainly into pulse proteins (e.g., peas, beans, chickpeas, lentils and lupines), oilseed proteins (soybeans, peanut, flaxseed and rapeseed/ canola), cereal proteins (wheat, corn, rice, oats, barley and sorghum) and also the so called "pseudocereal" proteins (quinoa, amaranth, chia and buckwheat) (Kyriakopoulou, Dekkers, \& van der Goot, 2019). Among all the plant proteins, currently in use by the food industry, the

\footnotetext{
* Corresponding author.

E-mail address: zita.avelar@ceb.uminho.pt (Z. Avelar).
} 
Table 1

Examples of recent studies reported in the literature evaluating the technological-functional properties of plant proteins.

\begin{tabular}{|c|c|c|c|c|c|c|c|c|}
\hline \multirow[t]{2}{*}{ Protein source } & & \multicolumn{6}{|c|}{ Technological-functional properties } & \multirow[t]{2}{*}{ Reference } \\
\hline & & Sol & WAC & OAC & Emul & Foam & Gel & \\
\hline \multirow[t]{6}{*}{ Pulse } & Bean & $\mathrm{X}$ & & & $\mathrm{X}$ & & & Rahmati, Koocheki, Varidi, and Kadkhodaee (2018) \\
\hline & Chickpea & $\mathrm{X}$ & & & $\mathrm{X}$ & & & Mokni Ghribi et al. (2015) \\
\hline & Lupin & & & & $\mathrm{X}$ & & & Burgos-Díaz et al. (2016) \\
\hline & Pea & $\mathrm{X}$ & $\mathrm{X}$ & $\mathrm{X}$ & $\mathrm{X}$ & $\mathrm{X}$ & & Stone, Nosworthy, Chiremba, House, and Nickerson (2019) \\
\hline & Pea & $\mathrm{X}$ & $\mathrm{X}$ & $\mathrm{X}$ & $\mathrm{X}$ & $\mathrm{X}$ & $\mathrm{X}$ & Zhao, Chen, Hemar, and Cui (2020) \\
\hline & Cowpea & & & & & & $\mathrm{X}$ & Peyrano, de Lamballerie, Speroni, and Avanza (2019) \\
\hline \multirow[t]{5}{*}{ Oilseeds } & Soy & $\mathrm{X}$ & $\mathrm{X}$ & $\mathrm{X}$ & $\mathrm{X}$ & $\mathrm{X}$ & & Stone et al. (2019) \\
\hline & Soy & $\mathrm{X}$ & $\mathrm{X}$ & $\mathrm{X}$ & $\mathrm{X}$ & $\mathrm{X}$ & $\mathrm{X}$ & Zhao, Chen, et al. (2020) \\
\hline & Canola & & & & & & $\mathrm{X}$ & Kim, Varankovich, and Nickerson (2016) \\
\hline & Peanut & $\mathrm{X}$ & $\mathrm{X}$ & & & & $\mathrm{X}$ & Li et al. (2020) \\
\hline & Peanut & $\mathrm{X}$ & $\mathrm{X}$ & $\mathrm{X}$ & $\mathrm{X}$ & & $\mathrm{X}$ & Zhang, Wang, Li, and Yan (2020) \\
\hline \multirow[t]{5}{*}{ Cereal } & Oat & & $\mathrm{X}$ & & & & $\mathrm{X}$ & Nieto Nieto et al. (2016) \\
\hline & Oat & & & & $\mathrm{X}$ & & & Zheng, Li, and Liu (2020) \\
\hline & Wheat & $\mathrm{X}$ & $\mathrm{X}$ & $\mathrm{X}$ & $\mathrm{X}$ & $\mathrm{X}$ & $\mathrm{X}$ & Zhao, Chen, et al. (2020) \\
\hline & Barley & $\mathrm{X}$ & $\mathrm{X}$ & $\mathrm{X}$ & $\mathrm{X}$ & $\mathrm{X}$ & & Stone et al. (2019) \\
\hline & Rice & $\mathrm{X}$ & $\mathrm{X}$ & $\mathrm{X}$ & $\mathrm{X}$ & $\mathrm{X}$ & $\mathrm{X}$ & Zhao, Chen, et al. (2020) \\
\hline \multirow[t]{4}{*}{ Pseudocereal } & Chia & $\mathrm{X}$ & $\mathrm{X}$ & $\mathrm{X}$ & $\mathrm{X}$ & & $\mathrm{X}$ & López et al. (2018) \\
\hline & Quinoa & $\mathrm{X}$ & $\mathrm{X}$ & $\mathrm{X}$ & $\mathrm{X}$ & $\mathrm{X}$ & $\mathrm{X}$ & Dakhili, Abdolalizadeh, Hosseini, Shojaee-Aliabadi, and Mirmoghtadaie (2019) \\
\hline & Quinoa & $\mathrm{X}$ & $\mathrm{X}$ & $\mathrm{X}$ & $\mathrm{X}$ & $\mathrm{X}$ & & Elsohaimy, Refaay, and Zaytoun (2015) \\
\hline & Amaranth & $\mathrm{X}$ & $\mathrm{X}$ & $\mathrm{X}$ & $\mathrm{X}$ & $\mathrm{X}$ & $\mathrm{X}$ & López, Galante, Raimundo, Spelzini, and Boeris (2019) \\
\hline
\end{tabular}

Abbreviations: Sol: solubility; WAC: water absorption capacity; OAC: oil absorption capacity; Emul: Emulsifying; Foam: Foaming; Gel: Gelation.

majority are derived from soybeans and wheat. However, these protein sources are known for being part of "The Big Eight" allergens (Koeberl, Clarke, \& Lopata, 2014). Therefore, other protein sources such as pea and rice have emerged over the last years as promising plant protein substitutes due to their recognized hypoallergenicity along with other advantageous attributes such as nutritional and biological value (Zhao, Chen, Hemar, \& Cui, 2020).

The first attempt to divide plant proteins in their different fractions occurred in the beginning of the 20th century, when Thomas B. Osborne proposed a classification system for plant proteins based on their solubility and extractability in different solvent (Osborne, 1908). The proposed system allowed the general division of plant proteins in four main classes: albumins, globulins, prolamins and glutelins. Albumins consist in a water-soluble protein fraction that can coagulate if heated, whereas globulins are insoluble in water but soluble in diluted salt solutions (e.g., $0.1 \mathrm{~mol} \mathrm{~L}^{-1} \mathrm{NaCl}$ ). Prolamins have the particularity of being resistant to heat and are both insoluble in water and saline solutions, although being soluble in concentrated (60-70\% v/v) aqueous alcohol solutions. Glutelins are also insoluble in water but diluted acid or alkali solution can be used to promote their solubilization and extraction (Lafarga, 2018). Over the years, protein fractionation has been refined and it is already established that these four major plant protein classes are still constituted by a complex combination of proteins. Moreover, depending on the plant (or even on the species or sub-species), the proportion of each protein group and their molecular size varies substantially. For instance, pulses and oilseeds proteins are mainly composed by albumins and globulins, whereas prolamins and glutelins are predominant in cereals. Additionally, due to their molecular structures, each one of these protein fractions display distinctive properties that could be useful for food applications (Day, 2013; Loveday, 2019). Besides their recognized nutritional value and biological activity (e.g., anti-cholesterol, anti-hypertensive, anti-oxidant, anti-inflammatory, anti-carcinogenic and anti-microbial), they also possess promising technological-functional properties (e.g., gelling, emulsifying, and foaming) that can be tailored to develop innovative protein systems at different scales (nano, micro and macro). Therefore, novel valuable ingredients for incorporation in complex food matrices could be developed by using proteins derived from such alternative sources as raw materials (Fasolin et al., 2019; Lafarga, 2018; Moreno-Valdespino, Luna-Vital, Camacho-Ruiz, \& Mojica, 2020; Sieniawska, Maciejewska-Turska, Świątek, \& Xiao, 2020). Some plant proteins (e.g., globulins) present limited solubility, which hampers the development of new functional ingredients, since this property is directly related with the ability to form gels, foams and emulsions. This limitation is often overcome by thermal processing of proteins, causing irreversible modifications in the proteins' structure. However, conventional thermal processing treatments are highly aggressive and frequently compromise the nutritional and sensorial profile of proteins (Aryee, Agyei, \& Udenigwe, 2018; Nicolai \& Chassenieux, 2019).

Ohmic heating $(\mathrm{OH})$ and high pressure processing (HPP), together with other novel technologies, are considered 'emerging high-potential technologies for tomorrow' (De Vries et al., 2018). These technologies, due to their established advantages in food safety, minimal loss of nutrients and energy efficiency are attracting increasing attention in the food scientific community, seeking to replace high cost and aggressive thermal treatments (De Vries et al., 2018; Han, Cai, Cheng, \& Sun, 2018; Queirós, Saraiva, \& da Silva, 2018). These novel technologies were primarily used to increase shelf-life and the nutritional value of foods, but more recently they have been gaining attention as tools to change proteins' structure and functional properties, with promising results in conventional proteins (Aryee et al., 2018). Nonetheless, to the best of our knowledge, there is still a significant lack of information regarding the potential impact of such emerging technologies on the structure and functional properties of plant proteins (Li, Ye, Tian, Pan, \& Wang, 2018; Queirós et al., 2018).

This review aims at providing an overview of the most promising technological-functional properties of plant proteins. It also includes a state-of-the-art regarding OH and HPP technologies as well as the influence of their associated principles of operation: moderate electric fields (MEF - which are associated to $\mathrm{OH}$ ) and high hydrostatic pressure (HHP - which is the main effective factor of HPP) on the structure and functional properties of plant proteins. Finally, we discuss new insights on how these emerging food processing technologies could impact proteins in complex food systems and the interaction between the processed proteins and other food components towards the development of novel, nutritious and healthy food.

\section{Technological-functional attributes of plant proteins}

The behavior of plant proteins within food systems is highly dependent on their technological-functional properties. In order to fully understand their behavior, protein structural features (i.e., amino acid composition, structure and conformation) must be considered and related with their technological-functional properties such as solubility, 
water/oil holding capacity, viscosity, aggregation mechanisms and interfacial properties, responsible for foaming and emulsion abilities (Lafarga, 2018). Besides the protein's intrinsic factors, functionality is also reliant on environmental factors such as $\mathrm{pH}$, temperature and ionic strength as well as on processing impact inherent to the selected methodology of extraction and/or purification (Aryee et al., 2018; Joshi, Adhikari, Aldred, Panozzo, \& Kasapis, 2011). Novel processing technologies, such as $\mathrm{OH}$ and HPP, also have an impact in tailoring protein's functionality (Li et al., 2018; Queirós et al., 2018) and considering the scope of this review, such effects will be particularly addressed (see section 4). Technological functionality of plant proteins, which is fundamentally dependent on physical and chemical attributes, ultimately influences texture, appearance and stability of food matrices (Pojić et al., 2018). Recent studies can be found in the literature regarding the characterization of proteins isolated from a wide number of plants in terms of their technological-functional properties as shown in Table 1. An overview of the technological-functional properties of plant proteins and their related parameters will be presented as follows.

\subsection{Protein solubility}

Solubility is an important parameter that must be assessed since it is directly associated with important functional properties such as gelling, emulsifying and foaming (Shevkani, Singh, Chen, Kaur, \& Yu, 2019). It is highly dependent on the balance of hydrophobic and hydrophilic residues present in the protein structure and on the protein's surface charge, and also on the solution's $\mathrm{pH}$, ionic strength, solvent type and temperature (Lafarga, 2018). Some studies with pulse proteins reported the positive association between solubility and surface charge whereas a negative relation occurs when relating solubility with surface hydrophobicity (Karaca, Low, \& Nickerson, 2011; Shevkani, Singh, Kaur, \& Rana, 2015). Solubility of plant proteins is also affected by the system's $\mathrm{pH}$. Namely, proteins are less soluble in a $\mathrm{pH}$ range around their isoelectric point, where the net charge of the protein is zero and protein-protein interactions favour aggregation due to the reduction of intermolecular electrostatic repulsion. In turn, their solubility is increased as the system's pH moves away from the isoelectric point (Bessada, Barreira, \& Oliveira, 2019; Karaca et al., 2011; Shevkani et al., 2019). Recently, Zhao, Shen, Wu, Zhang, and Xu (2020) studied the pH related solubility of distinct plant proteins, i.e., pea, soybean, wheat and rice. Their isoelectric point was estimated to be around $\mathrm{pH} 4-6,4-5$ and 6-7 for pea, soybean and wheat, respectively, at which protein precipitation was almost complete. Moreover, for wheat protein, a perfect " $U$ shape" curve was obtained in a $\mathrm{pH}$ /protein solubility graph indicating that both acidic and alkaline media, away from the isoelectric point, are suitable for protein's solubilization. Regarding soybean and pea proteins, the solubility profile was asymmetric, meaning that an alkaline medium is preferential to ensure a better protein solubility. On the other hand, rice proteins have shown to remain almost insoluble in the entire $\mathrm{pH}$ range (these results were in agreement with other studies reported in the literature) (Hefei Zhao, Chen, et al., 2020; Hoogenkamp, Kumagai, \& Wanasundara, 2017). In order to define potential food applications, it is then crucial to understand the distinct solubility mechanisms of selected proteins (Bessada et al., 2019).

\subsection{Water and oil/fat absorption capacities}

Proteins are recognized for their ability to hold water and oil/fat. Water absorption capacity (WAC) is expressed as the amount of water absorbed by $1 \mathrm{~g}$ of protein. On the other hand, fat/oil absorption capacity (FAC/OAC) is specified as the quantity of fat/oil that $1 \mathrm{~g}$ of protein powder or flour is able to absorb. These are considered two particularly important parameters, having a profound effect on texture (e.g., juiciness, tenderness and mouthfeel) and flavor retention (Bessada et al., 2019; Shevkani, Kaur, Kumar, \& Singh, 2015). Fat/oil absorption capacity is an extremely important parameter in the formulation of foods in which fat/oil impacts the textural food attributes (e.g., meat replacers/derivatives or ground meals) (Aryee et al., 2018; Tiwari \& Singh, 2012). On the other hand, WAC is a property that becomes crucial in foods with associated viscosity as soups, doughs and custards (Shevkani et al., 2019; Sreerama, Sashikala, Pratape, \& Singh, 2012). The location of polar amino acids in protein-water interaction sites has been related with WAC, while the nonpolar amino acids in protein-oil interaction sites largely determines FAC (Bessada et al., 2019; Boye, Zare, \& Pletch, 2010; Porras Saavedra, Guiémes-Vera, SOTO, Martínez, \& Yañez, 2013). Regarding pulse proteins, few studies reported large variations between the WAC and FAC/OAC of different pulses such as field pea, cowpea, kidney bean, chickpea, faba and lentil (Shevkani et al., 2019). Zhao and co-workers (2020) recently reported significant variations between WAC values of pulse, oilseed and cereal proteins. In this case, rice and wheat had the lowest WAC values (about $1 \mathrm{~g} / \mathrm{g}$ ), whereas WAC value for soybean and pea protein were about $3 \mathrm{~g} / \mathrm{g}$ and $5 \mathrm{~g} / \mathrm{g}$, respectively. In addition, regarding $\mathrm{OAC}$, all proteins in study presented similar values (Hefei Zhao, Chen, et al., 2020).

Thermal processing leads to protein denaturation, thus possibly causing the loss in their solubility, however the ability to retain water seems to be typically improved (Aryee \& Boye, 2017; Aryee et al., 2018). In fact, every process that may cause structural rearrangement in proteins may impact the hydrophobic/hydrophilic balance on the protein's surface, thus impacting its solubility and WAC or OAC. Emergent processing technologies could then constitute a viable option to avoid the detrimental effects of conventional thermal processing while affecting such parameters.

\subsection{Emulsifying and foaming properties}

Emulsifying and foaming properties of proteins play a crucial role in influencing the structure, stability and sensorial attributes in foods such as mousses, toppings, margarine, beverages or ice cream, (Aryee et al., 2018). Proteins are known for their amphiphilic nature (i.e., the presence of both polar and nonpolar amino acid residues). Their ability to be adsorbed at the interface of oil or air droplets allows the development of stable films and dispersions, thus acting as emulsifiers. The dispersion of oil droplets in an aqueous medium or the surrounding of air cells with a film leads to the formation of emulsions and foams, respectively (Bessada et al., 2019; Damodaran, 2005).

To measure the emulsifying properties of proteins, emulsifying activity index (EAI) and emulsifying stability index (ESI) must be determined. EAI consists in measuring the quantity of emulsified oil per $1 \mathrm{~g}$ of protein, whereas ESI determines the emulsion's resistance during a specific period (Boye, Zare, \& Pletch, 2010; Burger \& Zhang, 2019). Emulsifying capacity is directly influenced by both intrinsic protein attributes such as molecular weight, conformational stability, water solubility, amino acid composition and hydrophobicity-hydrophilicity ratio at the surface as well as by external parameters such as $\mathrm{pH}$, temperature and ionic strength (Bessada et al., 2019). Due to their emulsification properties, soy proteins have been explored more than other plant proteins (Burger \& Zhang, 2019; Day, 2013). Nevertheless, proteins from pulses, such as pea, lupin and chickpea, have demonstrated to possess emulsifying properties similar to soy proteins (Bessada et al., 2019; Burger \& Zhang, 2019; van de Noort, 2017). Over the last decades a significant variety of emulsifying properties has been reported in different plant proteins. For instance, the EAI and ESI of soybean, pea, wheat and rice protein were determined at $\mathrm{pH}$ 7. The results indicated that soybean and pea protein displayed similar emulsifying properties (above $100 \mathrm{~m}^{2} \mathrm{~g}^{-1}$ ) therefore, it seems reasonable to substitute soybean with pea protein in meat and sausage products. In contrast, wheat and rice protein displayed emulsifying properties significantly less evident (below $40 \mathrm{~m}^{2} \mathrm{~g}^{-1}$ and $20 \mathrm{~m}^{2} \mathrm{~g}^{-1}$, respectively) when compared with the others previously mentioned, thus, their use as emulsifiers appears to be limited at the studied $\mathrm{pH}$ (Zhao, Chen, et al., 2020). Other plant proteins such as those presented in rice bran displayed emulsifying properties 
comparable to casein (Fabian \& Ju, 2011; Hoogenkamp et al., 2017). Moreover, a recent study based on the phenomenon recognized as Pickering stabilization (where solid particles located at the interfacial surface of emulsion droplets protect them against coalescence by interfacial action), has successfully tailored zein and gliadin to behave as stabilizers in the preparation of stable oil-in-water emulsions (Liu, Huang, Chen, Deng, \& Yang, 2019).

As mentioned before, plant proteins also possess foaming properties, which are commonly evaluated in terms of foaming capacity (FC) and foaming stability (FS). FC consists in measuring the volume (\%) of incorporated air after whipping whereas FS is related to the foam stabilization (volume) during a specific period. There might be a relationship between protein's surface charge and foaming since a greater charge promotes the weakening of hydrophobic interactions, thus causing an increase in protein solubility, allowing them to quickly disperse on the interface and encapsulate air particles (Shevkani et al., 2019). Proteins such as pea and lupin, demonstrated to have good FC and FS, readily compared with egg and soybean proteins (Bessada et al., 2019; Wong, Pitts, Jayasena, \& Johnson, 2013; Zhao, Chen, et al., 2020). The emulsifying and foaming capacity of plant proteins, plus their similar behavior to some of the more established emulsifiers, make of these proteins interesting alternatives for use in the food industry.

\subsection{Gelation properties}

The ability to form gels under certain conditions is another essential protein functionality for the food industry, in particular for a variety of foods such as puddings, jellies and meat products where water retention, elasticity and texture are determinant attributes. Different physical or chemical methods, such as heat, pressure, chemical and enzymatic treatments may be applied to cause protein gelation (Aryee et al., 2018; Bessada et al., 2019). When protein unfolding occurs, hydrophobic amino acid residues become exposed, resulting in attractive forces between hydrophobic regions in different proteins. These interactions may be stabilized by other mechanisms (via disulphide bonds, hydrogen bonds, hydrophobic, van der Waals interactions) resulting in irreversible aggregation. The propagation of this phenomenon results in the formation of a three-dimensional network (if the protein concentration is high enough), thus forming a gel (Ramos et al., 2015). Many factors are responsible for influencing the protein's gel formation as well as final structure and associated mechanical properties (e.g., $\mathrm{pH}$, temperature, ionic strength, molecular weight along with the processing treatment and respective conditions) (Lin et al., 2017). The measurement of the protein's gelling capacity is performed by the minimal protein concentration that allows gelation to occur (designated as "least gelation concentration") (Zhao, Chen, et al., 2020). Some reports on heat-induced gelation of plant globulins from different sources (e.g., soy, pea, canola, quinoa, lupin, cotton seed and chia) have demonstrated their potential to form gels with different features. Some studies had also reached the conclusion that plant globulins gels are formed during heating in an analogous way of other globular proteins as dairy proteins. However, further research is still required to fully understand the gel forming mechanisms and also the subsequent comparison between different plant globulins and dairy proteins in which the process is much more established (Nicolai \& Chassenieux, 2019). Nonetheless, plant protein gels present interesting gelling capacities, suitable to specific applications and passible to be tuned during the production processes of the foods they are to be integrated in. Gels from lupin protein isolate (LPI) seem to be less strong when compared with a reference material such as soy protein isolate (SPI). Nonetheless, LPI gels constitute a good choice in the development of less viscous foods after the application of heat treatments (Berghout, Boom, \& van der Goot, 2015; Bessada et al., 2019). The impact of a pH-shifting treatment (subjecting peanut protein isolate (PPI) to a $\mathrm{pH} 10$ for $1 \mathrm{~h}$, followed by a shift back to $\mathrm{pH}$ 7) in the structure and heat-induced gel properties of PPI, resulted in a gel with significantly improved breaking force and water holding capacity. Such behavior was attributed to the decreased particle size, increased solubility, surface hydrophobicity and free sulfhydryl group content (J. Li et al., 2020). Thermal gelation of cowpea protein isolates and subsequent rheological characterization, demonstrated their versatility to be used as gelling agents. The introduction of a $\mathrm{pH}$ shifting treatment during protein extraction has also improved the mechanical properties of the obtained gels (Peyrano, de Lamballerie, Speroni, \& Avanza, 2019).

The combination of proteins with polysaccharides has also been explored for developing innovative gels with distinctive microstructure and sensory features along with improved functionality (Chu, Yang, Li, Lin, \& Zheng, 2019; Nieto; Haibo Zhao, Chen, et al., 2020; Nieto Nieto, Wang, Ozimek, \& Chen, 2016; Yan, Yin, Li, Yadav, \& Jia, 2020).

\section{Emergent food processing technologies}

\subsection{Ohmic heating $(\mathrm{OH})$}

The demand for alternatives to conventional thermal technologies in the food industry has led to the introduction of electric field-based process. $\mathrm{OH}$ is a thermo-electrical processing technology based on the passage of an electrical current through a food with an associated electrical resistance (Pereira \& Vicente, 2010). Its action can then be explained by the Joule's law, in which the passage of an electric current through a conductive (or semi-conductive) material generates heat. $\mathrm{OH}$ has the particularity of electrodes contacting directly with the foodstuff, and although a direct or alternating current can be applied to achieve $\mathrm{OH}$, it is advisable to use an alternating current because it prevents or restricts electrochemical and electrolytic reactions (Jaeger et al., 2016). Due to the direct energy dissipation in the food, heating occurs at a fast rate and homogeneous dissipation takes place. This results in the achievement of the target processing temperatures in a reduced treatment time, preventing excessive thermal damage to foodstuff (i.e., loss of sensorial and nutritional attributes) (Knirsch, Alves dos Santos, Martins de Oliveira Soares Vicente, \& Vessoni Penna, 2010; Pereira \& Vicente, 2010; Sakr \& Liu, 2014; Sastry, 2005; Silva, Santos, \& Silva, 2017). Additionally, $\mathrm{OH}$ has demonstrated to be beneficial in reducing surface fouling-related issues or even thermal abuses on the product due to the absence of hot surfaces and the inherent lack of heat transfer limitations. It is also considered an environmentally friendly processing technology due to the associated high energetic efficiencies (>95\%) and low maintenance costs (Kumar, 2018; Pereira \& Vicente, 2010). Usually, $\mathrm{OH}$ occurs within the specifications of MEF, in which the electric field is applied between 1 and $1000 \mathrm{~V} \mathrm{~cm}^{-1}$, the waveform is typically sinusoidal due to the easier production and modulation, frequency ranges between $1 \mathrm{~Hz}$ and $1 \mathrm{MHz}$ and the treatment time has no restrictions (Rodrigues, Fasolin, et al., 2020; Sastry, 2008). The distinction between $\mathrm{OH}$ and MEF is related with the intend effect: thermal action, which is related to $\mathrm{OH}$ or the electric field non thermal-effects (where heat generation is minimized or even restricted), linked with MEF. However, in practical applications, both effects occur simultaneously and it is not possible to strictly differentiate the thermal and electric effects (Rodrigues et al., 2019; Sastry, 2008).

Over the years, a wide number of potential applications of $\mathrm{OH}$ were presented, including low temperature, microbial inactivation, blanching, pasteurization, sterilization, dehydration, evaporation, fermentation, extraction, and also to heat food in long-duration space missions as well as in the military field (Kumar, 2018; Sastry et al., 2009). The industrial implementation of $\mathrm{OH}$ has been growing since the 1990s, with a steady increase in numbers of new manufacturers and commercial installations. As a matter of fact, the successful implementation of this technology made it possible to find commercially available food products that are currently being processed by OH. (Rodrigues et al., 2019; Sastry, 2008). 


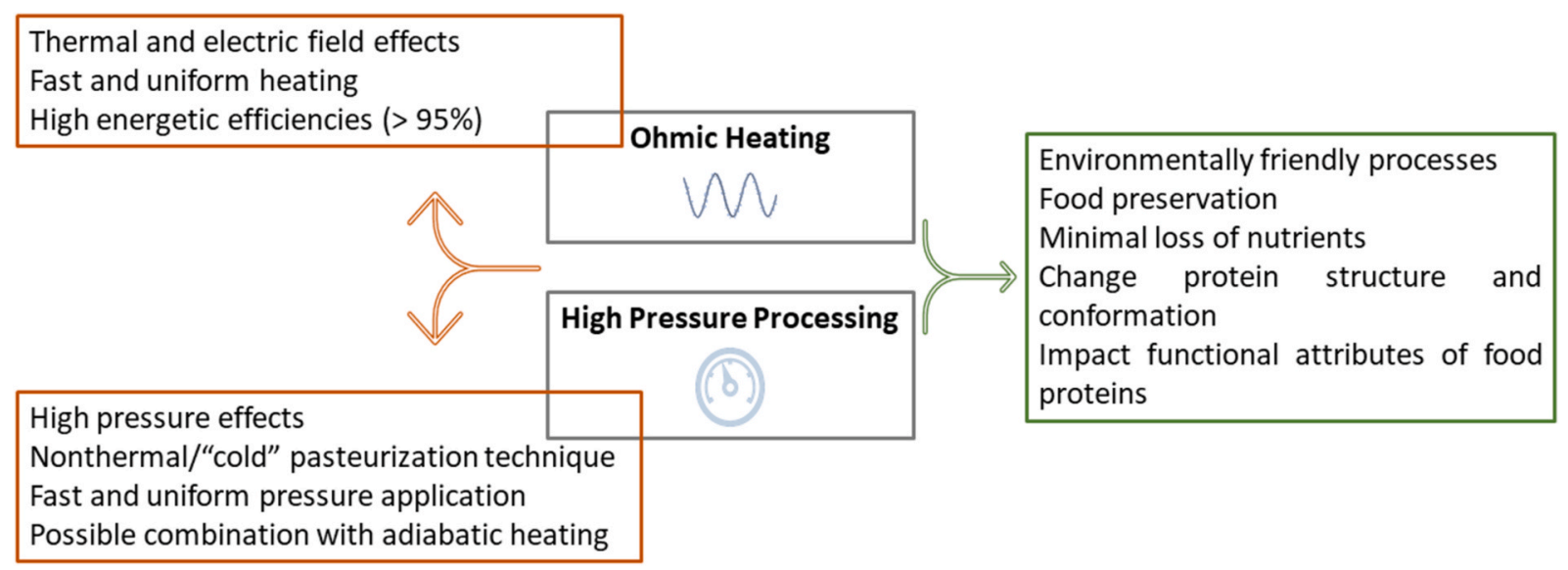

Fig. 1. Schematic framework of the main features of $\mathrm{OH}$ and HPP and their common effects on food processing.

\subsection{High pressure processing (HPP)}

HPP, also called high hydrostatic pressure processing or ultrahigh pressure processing, is a processing technology that has been used in the food industry to inactivate spoilage microorganisms and dangerous pathogens. In HPP, heat is substituted by pressure (ranging from 100 to $800 \mathrm{MPa}$ ), so it has been called as a nonthermal or "cold" pasteurization technique, avoiding the disadvantageous thermal effects on the sensorial and nutritional attributes of foods (Balasubramaniam et al., 2008, 2015; Muntean et al., 2016; Queirós et al., 2018). In order to foresee the impact of HPP on food it becomes necessary to understand some of the basic principles by which the behavior of foods under pressure is determined. The first one is known as the Le Chatelier's principle and describes the tendency of a system to shift towards the lowest volume by pressure application. The principle of microscopic ordering states the antagonistic forces of temperature and pressure on the molecular structure and chemical reactions, which means that when temperature remains constant, an increase in pressure leads to the increase of the ordering degree of molecules. At last, according to the isostatic principle, pressure and the correspondent effects are applied fast and homogeneously through the entire food product (with or without being packaged), no matter its volume, size, shape and composition (Balasubramaniam et al., 2015; Huppertz, Vasiljevic, Zisu, \& Deeth, 2019). HPP can be processed at a temperature from below $0{ }^{\circ} \mathrm{C}$ (to reduce eventual effects of adiabatic heat) to above $100{ }^{\circ} \mathrm{C}$ (Pereira \& Vicente, 2010). Cooling jackets, heat exchangers and recirculation of the cooling medium are used to control the processing temperature (Alexandre, Pinto, Moreira, Pintado, \& Saraiva, 2019). Regarding food preservation, this nonthermal technology yields numerous advantages: homogeneous treatment due to the uniform pressure application within the food product; shelf lives of treated samples are similar or even higher to those subjected to thermal pasteurization and the preservation of the food quality parameters is maintained; heat impact is minimal; low contamination risk and low energy consumption. For these reasons HPP is considered as an environmentally friendly processing technology (Huang, Wu, Lu, Shyu, \& Wang, 2017). Several factors are responsible for influencing the efficacy of HPP such as temperature, treatment time, food matrix characteristics, pressure level used and the nature of pressure (batch or continuous), type of microorganisms and packing material (Alexandre et al., 2019). Currently, this technology has been applied to the pasteurization of fruits, yogurts, sauces and salad dressings; pasteurization of meats and vegetables; decontamination of heat sensitive ingredients as vitamins and flavorings (Alexandre et al., 2019; Muntean et al., 2016).

Fig. 1 summarizes some relevant aspects of HPP and $\mathrm{OH}$ (as discussed in the previous subsection) as well as the common outputs generated through their application on food products/ingredients.

\section{Impact of $\mathrm{OH}$ and HPP on protein functionalization}

$\mathrm{OH}$ and HPP have established their potential in replacing conventional processing techniques by improving shelf-life (through microbial inactivation) and food quality (i.e., by avoiding or significantly reducing the negative changes in the sensorial and nutritional properties of foods) (Aryee et al., 2018). However, over the last few years, further research has been addressed on the potential effects of $\mathrm{OH}$ and HPP application in changing the inherent structure of proteins. This gave rise to the development of novel food ingredients such as gels and films with tailored functionality for different food applications. Currently, their ability to modulate proteins' structure and influence protein functionality is well described in the literature, particularly in the case of dairy proteins (Munir et al., 2019; Rodrigues et al., 2019). In fact, significant research has been developed regarding the denaturation and functional properties of whey proteins, due to their interesting technological properties and recognized biological value (Huppertz et al., 2019; Pereira et al., 2018). Promising results were obtained by the application of $\mathrm{OH}$ in modifying the denaturation and aggregation pathways of these bio-macromolecules, thus opening the possibility to develop innovative protein systems as gels, films and nano/micro structures with tailored functionality (Pereira, Teixeira, \& Vicente, 2011; Rodrigues et al., 2015). The impact of MEF effects during a OH treatment on whey protein isolate (WPI) solutions was recently established, from molecular to macroscopic levels. The application of $\mathrm{OH}$ to WPI solutions and the control of its variables (i.e., voltage and frequency), not only affected the protein denaturation and aggregation pathways but also allowed to control the gelation process and to modulate molecular interactions, influencing the protein network formation and thus determining the final gel properties (Rodrigues, Fasolin, et al., 2020).

Protein functionalization can also be promoted by the application of HPP. Considerable work has been focused on the mechanisms of unfolding and aggregation of $\beta$-Lactoglobulin $(\beta-\mathrm{Lg})$ during the application of HPP and after its release (Munir et al., 2019). This major whey protein fraction is known as the most sensitive to processing and thus largely dominates the HPP-induced denaturation, aggregation and gelation behavior of the whey protein systems (Huppertz et al., 2019). The effect of high pressure on the structure of whey proteins has been explained in detail as well as the proposed mechanisms underlying the pressure-induced unfolding and aggregation of $\beta$-Lg (López-Fandiño, 2006; Orlien, Olsen, \& Skibsted, 2007; Stapelfeldt \& Skibsted, 1999). The modification of their functional properties, such as gelation, foaming capacity and emulsifying activity has also been related with such pressure-induced structural changes (López-Fandiño, 2006).

Plant proteins have also demonstrated promising functional properties that often need to be improved, particularly by being submitted to conventional heat processing. Therefore, in the next subsections, the 


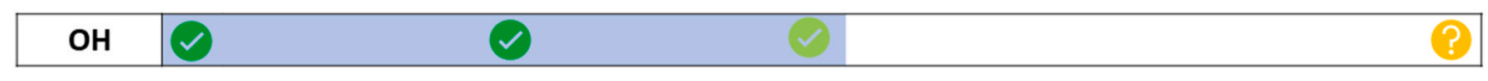

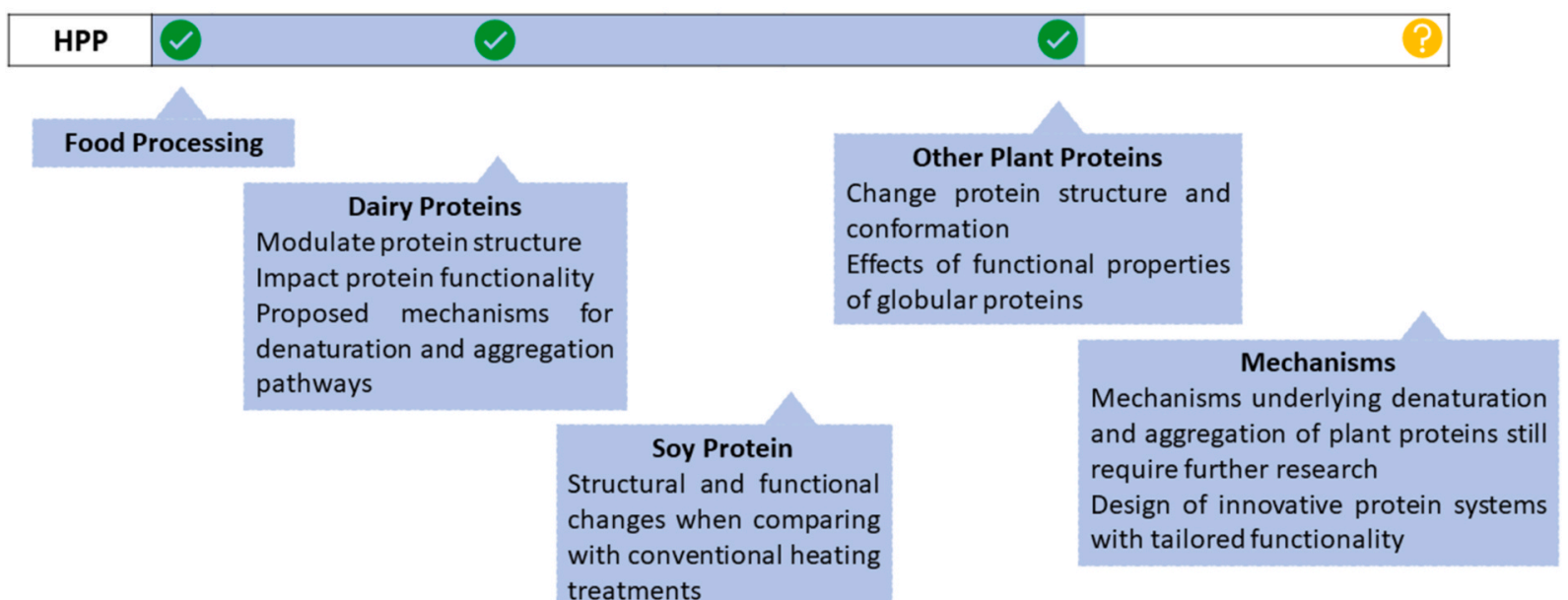

Fig. 2. Progress in research of plant protein functionalization under the effects of $\mathrm{OH}$ and $\mathrm{HPP}$.

available information on how OH and HPP affect the structure and functionality of these proteins will be gathered and critically discussed.

\subsection{Ohmic heating}

Currently, few reports can be found in the literature regarding the application of $\mathrm{OH}$ on plant protein-based foods and their effects on plant protein structure and functional properties. In contrast, extensive research has been developed on conventional proteins and correspondent based-foods, such as meat, eggs and dairy. Furthermore, the available information reported in the literature was mainly related to soy protein and its derived food products such as tofu. In fact, the $\mathrm{OH}$ processing of soymilk to induce its coagulation for production of tofu has shown promising results in the textural properties of the final product (Shimoyamada et al., 2015; Wang et al., 2007). In addition, an opposite relation was found between the voltage applied and the viscosity, precipitation and surface hydrophobicity of soy protein (Shimoyamada et al., 2015). Li et al. (2018), in more fundamental studies, explored the effects of $\mathrm{OH}$ on the structure and functional properties of protein in soybean milk. It was verified that significant changes occurred in the structure and functional properties of proteins, when compared to the traditional heating method (Li et al., 2018). It was also suggested that the modifications in total sulfhydryl content, surface hydrophobicity and functional properties such as foaming and emulsification capacity were induced by the application of electric fields inherent to $\mathrm{OH}$ (Cha, 2011; X.; Li et al., 2018). The formation of protein-lipid films by the application of $\mathrm{OH}$ to promote heating of soymilk was also explored. Lei, Zhi, Xiujin, Takasuke, and Zaigui (2007) have demonstrated the successful production of films with better yield, film formation rate, rehydration capacity and protein incorporation efficiency (Lei et al., 2007). Recently, it was also evaluated the impact of $\mathrm{OH}$ in the structural and thermo-physical properties of sunflower protein isolate (SPI). MEF during a $\mathrm{OH}$ treatment significantly reduced the average protein particle size, affecting homogeneity as well as the surface tension of SPI solutions. Moreover, the tertiary structure of SPI was changed and a decrease in the denaturation temperatures and enthalpies of SPI samples was also observed (Subaşı et al., 2021).

Even though there are now compelling evidences mostly on the modifications induced in soy proteins and soy protein-based foods by the use of $\mathrm{OH}$, the mechanisms underlying their denaturation and aggregation still require further research. Particularly the impact of $\mathrm{OH}$ effects on soy protein from macroscopic to molecular scale must be established, thus allowing the control of their functional behavior and the development of new food ingredients. Furthermore, additional efforts to determine the effects of $\mathrm{OH}$ on the structure and functional properties of other plant proteins remain essential. This field can then benefit from the more established knowledge of $\mathrm{OH}$ effects on conventional proteins and transfer the developed methodologies and protocols to accelerate its development in plant proteins (as shown in Fig. 2).

\subsection{High pressure processing}

HPP-induced changes on plant proteins have been reported in the literature over the last few years. Furthermore, research has also been focused on how the application of pressure allows tailoring certain functional attributes such as the capacity to form aggregates or gels, or even, their ability to stabilize emulsions and foams, for different food applications (Queirós et al., 2018).

Pressure has a profound impact on protein denaturation and final conformation, by inducing modifications in their structure at different levels (Gharibzahedi \& Smith, 2021; Huppertz et al., 2019; Messens, Van Camp, \& Huyghebaert, 1997). In fact, only noncovalent bonds, e.g., hydrogen, ionic and hydrophobic bonds are affected by HPP while the covalent bonds, which have very low compressibility at high pressure, remain relatively intact (Considine, Kelly, Fitzgerald, Hill, \& Sleator, 2008). Therefore, the protein's primary structure remains almost intact owing to the covalent bonds, while the secondary, tertiary and quaternary structures can be affected, because their ionic, hydrophobic, hydrogen bonds and the electrostatic interactions can be disrupted (Rendueles et al., 2011; Yang, 2016). Generally, the primary structure is only affected by pressures above $2 \mathrm{GPa}$ and the secondary and tertiary/quaternary structures are mostly compromised by lower pressure values of $>400$ and $100-200 \mathrm{MPa}$, respectively (Knorr, Heinz, \& Buckow, 2006; Winter, Lopes, Grudzielanek, \& Vogtt, 2007). Recently, several studies were reviewed concerning the effect of HPP on the secondary structure of different plant proteins, having stated that the type of protein, environmental conditions and concentration highly affects the impact of pressure on the plant protein's secondary structure (Queirós et al., 2018).

HPP is now established as a nonthermal processing technology capable of modifying protein structure and affecting the physicochemical forces and interactions between protein molecules of dispersion system, including surface hydrophobicity, electrostatic interaction, disulphide linkages and hydrogen bonding ( $\mathrm{He}, \mathrm{He}$, Chao, Ju, \& Aluko, 2014; Wang et al., 2017). Thus, it is not surprising that, under specific conditions, HPP-induced modifications may lead to protein unfolding, 
aggregation and ultimately to gel by the formation of a three-dimensional protein network system (De Maria, Ferrari, \& Maresca, 2016; Ma et al., 2013; Zhao, Mu, Zhang, \& Richel, 2018a). Recently, Queirós et al. (2018) reported that two distinct strategies were being used in the studies developed so far, one consists in study the formation of a gel by submitting the protein solution to HPP, the other is related with pre-treating the protein solution under HPP effects, below the concentration required to gelation and then recovering the HPP-treated solution to study the heat-induce gelation. Regarding the first reported strategy, it was highlighted the importance of protein concentration in the production of gels and their final rheological behavior. In the second case, pre-treatment generally decreases the minimum protein concentration that becomes necessary to allow the subsequent gelation by heating (Queirós et al., 2018).

When studying sweet potato protein gels induced by HPP, it was found a strong dependence of the rheological properties as a function of the system's pH. Gels formed by the application of $400 \mathrm{MPa}$, at three distinct $\mathrm{pH}$ values ( $\mathrm{pH}$ 9.0, 6.0 and 3.0), would all constitute a reasonable option for developing novel food ingredients, but gels formed at the higher pH values presented better performances (Zhao et al., 2018a). In other studies conducted by the same authors it was demonstrated that a combination of HPP with a microbial transglutaminase treatment (Zhao, Mu, Zhang, \& Richel, 2019) and the addition of salt ions (Zhao, Mu, Zhang, \& Richel, 2018b) had a positive impact in the textural properties of the formed gels. Further research has continued to demonstrate the positive impact of HPP pre-treatment in the rheological behavior of heat-induced cowpea protein gels (Peyrano, de Lamballerie, Avanza, \& Speroni, 2019) and wheat gluten gels (Wang et al., 2019). HPP also impacts the formation of pseudocereal protein-based films, having demonstrated a better uniformity, better mechanical properties, lower water vapor permeability and water solubility when compared to the non-treated protein system. In addition, HP-treated films presented improved functionality when compared to those that were thermally treated (Condés, Añón, \& Mauri, 2015).

Chao, Jung, and Aluko (2018), recently reported an enhanced emulsion formation and foaming capacity of pea proteins when submitted to HPP treatment at a pH 3.0 (Chao et al., 2018). Other studies have also been performed on distinct plant proteins to assess the effects of HPP on other functional properties such as oil-in-water emulsion-forming ability and foaming properties. The obtained results are diverse, such as improvement, decrease and even the inexistence of changes in emulsifying and foaming properties. Such distinctive behavior appears to be resultant from the type of protein in study, solution conditions and processing conditions (e.g., the applied pressure), thus its interpretation must be considered case by case. In order to fully understand the structure/function relationship of these proteins under HPP, changes in surfactant properties and the interfacial adsorption processes must be further enlighten to achieve the desired emulsifying and foaming properties to the intended use (Baier \& Knorr, 2015; Galazka, Dickinson, \& Ledward, 2000; Khan, Mu, Sun, Zhang, \& Chen, 2015; Li, Zhu, Zhou, \& Peng, 2011; Qin et al., 2013; Queirós et al., 2018; Yin, Tang, Wen, Yang, \& Li, 2008; Zhao, Zhou, Zhang, Ni, \& Li, 2015; Zhou et al., 2016).

Despite the advances in this area of knowledge, the exact correlation between the modifications in protein structure and the change in functionality remains to be completely unveiled. Therefore, further research is required in order to allow the development of protein systems with tailored functionality, envisioning specific applications (as shown in Fig. 2).

\section{Design of complex food systems}

The established ability of $\mathrm{OH}$ and HPP in tailoring protein functionality, coupled with a minimized environmental impact, make of these emergent processing technologies valuable tools to the development of novel and highly functional multi-component food matrices. Such concept, although fundamental to fulfil the current global trends, must be developed along with nutritional and health aspects. This is fundamental to ensure the development of functional food from new renewable sources, capable of delivering the nutritional needs and promote the general health and wellbeing of the population.

\subsection{Interaction with other food components}

In multi-component food systems, the interactions between different protein fractions, other components or additives inevitably occur, with a high potential for these interactions to affect the properties of the final food product (James Harper, 2014; Lin et al., 2017; Queirós et al., 2018). For that reason, it becomes necessary to understand the synergistic effects of the presence of other food constituents during OH and HPP action on the structure and functionality of proteins integrated in the food system. However, that knowledge is still scarce and only a few studies can be found in the literature.

During the last few years, it has been demonstrated that the presence of MEF during a $\mathrm{OH}$ treatment can affect the unfolding, denaturation and aggregation pathways of numerous globular proteins, mainly from animal sources. More recently, it was even demonstrated how MEF can be applied to control the gelation process of whey proteins (Rodrigues, Avelar, et al., 2020). However, with regard to their impact on plant proteins functionalization, this is an area that clearly requires further research, as reviewed in the previous subsection (4.1). Likewise, the influence of protein-protein interactions and of the interactions of proteins with other food constituents (such as polysaccharides and bioactive compounds, e.g., vitamins) is still not unveiled.

Regarding HPP, there are a few studies dealing with this topic. One of the first published reports dates back to 1994, in which it was demonstrated the influence of salts $(\mathrm{NaCl}, \mathrm{LiCl}$ and $\mathrm{KCl})$ and glycerol in the inhibition of the high pressure-induced dissociation of vicilin, the $7 \mathrm{~S}$ storage pea's protein (Pedrosa \& Ferreira, 1994). Other authors have also observed that the presence of $\mathrm{NaCl}$ (Añón, de Lamballerie, \& Speroni, 2011) and Ca (Speroni, Añón, \& de Lamballerie, 2010) had an influence on soybean proteins subjected to HPP, being clearly dependent on the value of applied pressure and the salt/mineral concentration. The conjugation of plant proteins with polysaccharides to form fine complexes has been reported in the literature (Lin et al., 2017). Moreover, although still scarce, few studies can be found regarding the effects caused by the addition of polysaccharides to HPP-treated plant proteins, with indication to the existence of two distinct outcomes (Queirós et al., 2018). The first is related with an improvement in the emulsifying properties of vegetable proteins such as sweet potato protein (Khan, Mu, Ali, et al., 2015) and 11 S globulin of Vicia faba (Galazka, Dickinson, \& Ledward, 1999), due to their interaction with guar gum and carrageenan, respectively. The other one with the decrease in protein aggregation during or after the application of HHP during a HPP treatment (Galazka et al., 2000; Galazka et al., 2000). Generally, polysaccharides appear to play a protective role against protein unfolding and protein-protein aggregation after HPP treatment, thus preventing the loss in protein's functionality (Galazka et al., 2000). The change in the structural and functional properties of soy protein isolate (SPI) by glycation with flaxseed gum (FG) through the Maillard reaction under HPP was hypothesized (Liu et al., 2020). By monitoring changes in SPI, the authors have reported an improvement in solubility of SPI glycated with $\mathrm{FG}$, reaching $86.84 \%$ for the treatment of SPI-FG at pH 8 and $200 \mathrm{MPa}$. The control of glycation by HPP proved to be an effective strategy to improve SPI processability and applicability. The interaction between plant proteins and polyphenols has also been studied. However, the main focus of the studies has been related with the antioxidant properties or encapsulation and not so much with the eventual modification of proteins' properties due to the addition of the phenolic compounds investigated (Jin et al., 2021; Kadam, Palamthodi, \& Lele, 2019; Pham, Wang, Zisu, \& Adhikari, 2019; Ribnicky et al., 2014; Tapal \& Tiku, 2012; Xiang, Sun-waterhouse, Cui, Wang, \& Dong, 2018). Nevertheless, there are evidences that the application of HHP during a HPP treatment to 


\section{Emergent Processing Technologies}

\section{Native protein}
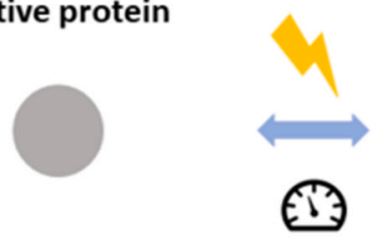

Denaturation

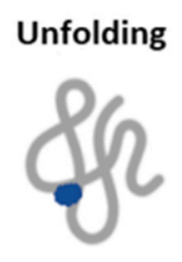

Protein aggregation
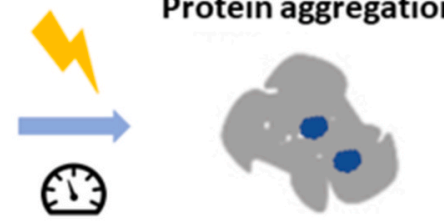

Irreversible denaturation

\section{Gastrointestinal digestion}

Ohmic heating

High pressure processing

Hydrophobic regions

\section{Gastrointestinal enzymes}

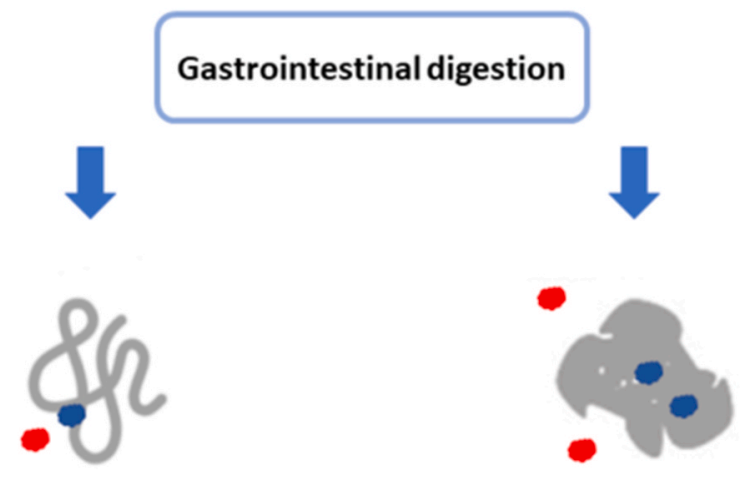

Fig. 3. Proposed influence of $\mathrm{OH}$ and HPP on protein gastrointestinal digestion.

modify proteins' properties may also influence the way proteins and polyphenols interact with each other, yet so far this has not been completely elucidated. In this context, the interactions between tea polyphenols (TP) and HPP-treated soybean protein (SP) were recently evaluated. The combination of TP and HPP treatment displayed a synergistic effect in solubility and emulsifying activity of SP, thus suggesting this interactions can be enhanced and bring advantages on the technological-functional properties of proteins (Chen, Wang, Feng, Jiang, \& Miao, 2019).

\subsection{Nutritional balance}

Beyond the technological-functional role of proteins in foods that in many cases dictates food structure, stability and organoleptic profile, proteins are also dietary macronutrients with important structural and functional roles in the human body (Loveday, 2019; Sá, Moreno, \& Carciofi, 2019). Nowadays, the consumers' awareness of the importance of diet and the promotion of health beyond nutrition has led to an increase of consumption of (perceived to be) healthier foods. For that reason, numerous plant protein sources (e.g., cereals, legumes, oilseeds, pulses and pseudocereals) have been comprehensively studied because of their composition rich in protein, fibers, minerals and other bioactive compounds with the aim of using them to the development of nutritionally improved food products (Arribas et al., 2017; Coda, Varis, Verni, Rizzello, \& Katina, 2017).

From a nutritional point of view, proteins from plants may be considered inferior to those of animal origin since they often present a deficiency in some of the 9 essential amino acids composition (Arribas et al., 2017). Essential amino acids (histidine, isoleucine, leucine, lysine, methionine, phenylalanine, tryptophan, threonine, and valine) correspond to those not being synthetized by the human body and thus, they only can be obtained by food intake (Lafarga, 2018). In general, cereal proteins possess low values of lysine while legume derived-proteins possess low levels of essential sulfur-containing amino acids (methionine and cysteine) (Neacsu et al., 2017; Pencharz, Elango, \& Wolfe, 2016). Besides that, they often possess some compounds designated as antinutritional factors, that are commonly considered responsible for plant protein deficiency. These so-called antinutritional factors are responsible for decreasing protein digestibility and inhibiting their bioavailability and thereby, limiting their nutritional value (Espinosa-Páez et al., 2017; Giami, 2004; Sá et al., 2019; Zhang, Liu, Ying, Sanguansri, \& Augustin, 2017). They include antinutritional proteins such as lectins and trypsin inhibitors and antinutritional chemicals such as phytates, tannins, and polyphenols (Adenekan, Fadimu, Odunmbaku, \& Oke, 2018; Alonso, Aguirre, \& Marzo, 2000; Arribas et al., 2017; Drulyte \& Orlien, 2019; Espinosa-Páez et al., 2017; Tuśnio et al., 2017). The application of conventional processing techniques (e.g., cooking, autoclaving, germination, extrusion and fermentation) to reduce or eliminate these antinutritional compounds is well established. Nonetheless, such techniques, mainly those applying aggressive heat treatments, are often detrimental to other food constituents, so processing technologies that are applied under mild conditions are preferable (Sá et al., 2019). OH and HPP, alone or combined, may constitute a good alternative to the inactivation of such compounds under gentle temperatures, considering their already established success in modifying numerous food properties.

The issue related with the amino acid deficiency could be overcome by protein complementation, i.e., blending cereal proteins with legume proteins as a strategy to develop a more nutritious food product (Arribas et al., 2017; Pencharz et al., 2016). Moreover, as discussed in a previous subsection (5.1), the combination of plant proteins with other polymers (other proteins, from both animal or plant origin, or even polysaccharides) can be used to not only develop novel and highly functional complex food systems, but also to contribute to their balanced nutritional value (Lin et al., 2017).

\subsection{Protein digestibility}

Digestibility of food proteins is a measure of their susceptibility to be hydrolysed by the enzymes present in the gastrointestinal tract, being reliant on the structure of proteins, the presence of other food components, in particular antinutritional factors and the eventually applied 
Table 2

Changing the digestibility of plant proteins by the application of HPP.

\begin{tabular}{|c|c|c|c|c|}
\hline $\begin{array}{l}\text { Plant } \\
\text { proteins }\end{array}$ & Approach & $\begin{array}{l}\text { HPP } \\
\text { conditions }\end{array}$ & Output & Reference \\
\hline $\begin{array}{l}\text { Split pea } \\
\text { protein }\end{array}$ & $\begin{array}{l}\text { Pre- } \\
\text { treatment }\end{array}$ & $\begin{array}{l}100 \text { or } 600 \\
\mathrm{MPa} / 30 \text { or } \\
60 \\
\mathrm{Min} / 20 \text { or } \\
60^{\circ} \mathrm{C}\end{array}$ & $\begin{array}{l}\text { Protein } \\
\text { digestibility } \\
\text { increased by up } \\
\text { to } 4.3 \% \text { in peas } \\
\text { when treated at } \\
600 \mathrm{MPa} \text { and } \\
60^{\circ} \mathrm{C} \text {, } \\
\text { regardless of } \\
\text { time }\end{array}$ & $\begin{array}{l}\text { Linsberger-Martin, } \\
\text { Weiglhofer, Thi } \\
\text { Phuong, and } \\
\text { Berghofer (2013) }\end{array}$ \\
\hline $\begin{array}{l}\text { Kidney } \\
\text { bean } \\
\text { protein } \\
\text { isolate }\end{array}$ & $\begin{array}{l}\text { HPP- } \\
\text { assisted } \\
\text { enzymatic } \\
\text { hydrolysis }\end{array}$ & $\begin{array}{l}300-600 \\
\mathrm{MPa} / 15 \\
\min \end{array}$ & $\begin{array}{l}\text { Improvement } \\
\text { of alcalase } \\
\text { activity and } \\
\text { production of } \\
\text { the highest } \\
\text { degree of } \\
\text { hydrolysis } \\
(23.9 \%) \text { at } 300 \\
\text { MPa }\end{array}$ & $\begin{array}{l}\text { Al-Ruwaih et al. } \\
\text { (2019) }\end{array}$ \\
\hline $\begin{array}{c}\text { Red bean } \\
\text { protein } \\
\text { isolate }\end{array}$ & $\begin{array}{l}\text { Pre- } \\
\text { treatment }\end{array}$ & $\begin{array}{l}400,500, \\
\text { and } 600 \\
\mathrm{MPa} / 5 \\
\mathrm{~min} / 25^{\circ} \mathrm{C}\end{array}$ & $\begin{array}{l}\text { IVPD }{ }^{\mathrm{a}} \text { values } \\
\text { for HPP } 600 \\
\text { MPa treated } \\
\text { samples } \\
\text { increased from } \\
79.3 \% \text { to } 83.8 \% \\
\text { compared with } \\
\text { untreated } \\
\text { samples }\end{array}$ & Lee et al. (2018) \\
\hline $\begin{array}{c}\text { Flaxseed } \\
\text { protein } \\
\text { isolate }\end{array}$ & $\begin{array}{l}\text { HPP- } \\
\text { assisted } \\
\text { enzymatic } \\
\text { hydrolysis }\end{array}$ & $\begin{array}{l}100 \text { and } \\
300 \mathrm{MPa} / \\
5 \text { and } 10 \\
\text { min }\end{array}$ & $\begin{array}{l}\text { A pressure level } \\
\text { of } 300 \mathrm{MPa} \text { for } \\
10 \mathrm{~min} \\
\text { improved the } \\
\text { degree of } \\
\text { hydrolysis by } \\
1.7 \text { times as } \\
\text { compared to } \\
\text { that of the } \\
\text { control }\end{array}$ & Franck et al. (2019) \\
\hline $\begin{array}{l}\text { Soy } \\
\text { protein } \\
\text { isolate }\end{array}$ & $\begin{array}{l}\text { Pre- } \\
\text { treatment }\end{array}$ & $\begin{array}{l}200-300 \\
\mathrm{MPa}, 15 \\
\min , \\
20{ }^{\circ} \mathrm{C}\end{array}$ & $\begin{array}{l}\text { The } \% \mathrm{~N} \text { release } \\
\text { at the end of } \\
\text { pepsin and } \\
\text { trypsin } \\
\text { digestion for } \\
\text { samples treated } \\
\text { at } 300 \mathrm{MPa} / 15 \\
\text { min } \\
\text { significantly } \\
\text { increased by } 6 \\
\text { and } 7 \% \text {, } \\
\text { respectively, in } \\
\text { comparison } \\
\text { with the native } \\
\text { protein }\end{array}$ & Li et al. (2011) \\
\hline $\begin{array}{l}\text { White } \\
\text { bean } \\
\text { protein }\end{array}$ & $\begin{array}{l}\text { HPP pre- } \\
\text { treatment }\end{array}$ & $\begin{array}{l}200 \text { or } 400 \\
\mathrm{MPa} / 30 \text { or } \\
60 \\
\mathrm{Min} / 20 \text { or } \\
60^{\circ} \mathrm{C}\end{array}$ & $\begin{array}{l}\text { Protein } \\
\text { digestibility } \\
\text { increased by } \\
8.7 \% \text { in beans } \\
\text { treated at } 600 \\
\text { MPa at } 60^{\circ} \mathrm{C} \\
\text { for } 60 \mathrm{~min}\end{array}$ & $\begin{array}{l}\text { Linsberger-Martin } \\
\text { et al. (2013) }\end{array}$ \\
\hline
\end{tabular}

${ }^{a}$ IVPD (In vitro protein digestibility).

processing technology (Loveday, 2019; Sá et al., 2019).

$\mathrm{OH}$ and HPP are currently recognized as valuable tools in the maintenance of the nutritional and sensorial attributes of proteins along with impacting their structure. It is then anticipated that such ecoinnovative processing technologies could not only affect functionality but also play an important role in affecting proteins' nutritional value. To our best knowledge, the available information in the literature, connecting the application of such emergent processing technologies to plant protein and how it will affect their behavior within the gastrointestinal tract, remains scarce, so further research is needed in order to understand how these processes affect proteins' structure and its impact in gastrointestinal digestion and absorption. Fig. 3 illustrates the possible impact of OH and HPP on protein denaturation, threedimensional structure of food proteins and therefore on their behavior towards gastrointestinal digestion.

Besides the profound influence on the functional and organoleptic attributes of food, proteins and peptides possess numerous bioactive properties, such as, antidiabetic, antihypertensive, cholesterol-lowering, antimicrobial, anti-cancer, immunomodulatory, anti-inflammatory, ability to bind vitamins and minerals among others with great importance for human health and body functions (Daliri, Oh, \& Lee, 2017; Hernández-Ledesma, García-Nebot, Fernández-Tomé, Amigo, \& Recio, 2014; Udenigwe \& Aluko, 2012). However, bioactive peptides generally remain inactive within their polypeptide backbone and, during food digestion, partial hydrolysis by proteolytic enzymes allows their release and the generation of bioactivity (Chalamaiah, Yu, \& Wu, 2018; Evangelho et al., 2017).

The digestibility of proteins and the release of bioactive peptides has been improved by the application of HPP as a pre-treatment followed by enzymatic hydrolysis or during enzymatic hydrolysis (Queirós et al., 2018) (see Table 2). A study conducted on pea protein isolate has shown the beneficial effect that HPP pre-treatment had on its digestibility since it has enhanced the degree and rate of proteolysis. It was suggested that the unfolding of globular pea proteins has occurred, allowing hydrophobic groups to be exposed to pepsin (Laguna, Picouet, Guàrdia, Renard, \& Sarkar, 2017). HPP (300-600 MPa for $15 \mathrm{~min}$ ) assisted enzymatic proteolysis (using Alcalase) of kidney bean protein isolate (KBPI) was performed by Al-Ruwaih, Ahmed, Mulla, and Arfat (2019). It was concluded that high pressure facilitated the enzymatic hydrolysis of KBPI. In fact, alcalase activity was improved and produced the highest degree of hydrolysis (23.9\%) at $300 \mathrm{MPa}$, probably due to the unfolding of protein structure and the exposure of cleavage sites, facilitating protein hydrolysis. The same treatment has also increased the antioxidant activity of the hydrolysates (Al-Ruwaih et al., 2019). Franck et al. (2019) assessed the HPP (100 and $300 \mathrm{MPa}$ for 5 and $10 \mathrm{~min}$ ) assisted enzymatic hydrolysis of flaxseed protein isolate using trypsin. The degree of hydrolysis and antioxidant activity were significantly improved by an applied pressure of $300 \mathrm{MPa}$ for $10 \mathrm{~min}$. It was also suggested that the extent of hydrolysis and the obtention of smaller peptides through HPP-assisted enzymatic hydrolysis was related with the improvement in antioxidant capacity (Franck et al., 2019).

When considering $\mathrm{OH}$ processing, no available data on the digestibility of processed plant proteins could be found in the literature. However, it can be extrapolated from studies involving other conventional proteins sources (e.g., milk and egg) that this technology can have a significant impact on the proteins' behavior through the gastrointestinal tract. HPP and $\mathrm{OH}$ may bring the opportunity to improve the digestibility of plant proteins and the generation of bioactive peptides. Nevertheless, particularly in the case of MEF application during a $\mathrm{OH}$ treatment to plant proteins, research should be addressed to fully understand its implications.

\section{Conclusions}

Global nutritional trends have been shifting towards the consumption of novel and sustainable substitutes to animal-based proteins. Thus, the development of food alternatives that not only meet consumers' requirements towards animal protein substitution but are also able to accomplish the human requirements in terms of health/wellbeing and nutrition should be a priority for food researchers and industry.

Fundamental research concerning the relationship between structural changes and functionality of more conventional proteins such as soy, pea, kidney bean, cowpea, rice or lupin is still needed along with upcoming research on proteins from less studied sources that display both functional and quality parameters of interest to replace those from animal origin. 
Feeding the world population sustainably also requires the use of eco-innovative and cost-effective processing technologies such as HPP and $\mathrm{OH}$. Moreover, the application of pressure and electrical effects has been shown to have an important role in the functional attributes of food proteins, while ensuring the maintenance in their quality parameters and acting as effective tools to the preservation of food. There are currently strong indications on how plant proteins can be affected by HPP and OH. However, their tailoring to prepare a wide range of structures (e.g., micro or nanostructures, gels or films) for food incorporation/combination with other food components towards the design of complex food systems is far from being understood. Therefore, upcoming research regarding this topic is highly required.

Nutritional and health/wellness aspects must also be considered along with functionality. Future evaluation regarding the nutritional balance of novel multicomponent systems and the behavior of such processed proteins during their passage through the gastrointestinal tract (digestibility and bioavailability) is also of great interest.

\section{Credit author statement}

Zita Avelar: Conceptualization, Investigation, Writing - Original Draft. Rui M. Rodrigues: Conceptualization, Writing - Review and Editing, Supervision. António A Vicente: Writing - Review and Editing, Supervision. Jorge A. Saraiva: Writing - Review and Editing, Supervision.

\section{Declaration of competing interest}

The authors declare that they have no known competing financial interests or personal relationships that could have appeared to influence the work reported in this paper.

\section{Acknowledgements}

This study was supported by the Portuguese Foundation for Science and Technology (FCT) under the scope of the strategic funding of UIDB/ 04469/2020 unit and BioTecNorte operation (NORTE-01-0145-FEDER000004) funded by the European Regional Development Fund under the scope of Norte2020 - Programa Operacional Regional do Norte. Acknowledgments are also due to University of Aveiro and FCT/MCT for the financial support for LAQV-REQUIMTE research Unit (FCT UIDB/ $50006 / 2020$ ) through national funds and, where applicable, cofinanced by the FEDER, within the PT2020 Partnership Agreement. Zita Avelar acknowledges the Foundation for Science and Technology (FCT) for its fellowship SFRH/BD/146347/2019.

\section{References}

Adenekan, M. K., Fadimu, G. J., Odunmbaku, L. A., \& Oke, E. K. (2018). Effect of isolation techniques on the characteristics of pigeon pea (Cajanus cajan) protein isolates. Food Sciences and Nutrition, 6(1), 146-152. https://doi.org/10.1002/ fsn 3.539

Al-Ruwaih, N., Ahmed, J., Mulla, M. F., \& Arfat, Y. A. (2019). High-pressure assisted enzymatic proteolysis of kidney beans protein isolates and characterization of hydrolysates by functional, structural, rheological and antioxidant properties. $L W T$, 100, 231-236. https://doi.org/10.1016/j.lwt.2018.10.074

Alexandre, E. M. C., Pinto, C. A., Moreira, S. A., Pintado, M., Saraiva, J. A., \& C. M. B. T. S. F. Galanakis. (2019). 5 - nonthermal food processing/preservation technologies. In Saving food (pp. 141-169). Academic Press. https://doi.org/10.1016/B978-0-12815357-4.00005-5.

Alonso, R., Aguirre, A., \& Marzo, F. (2000). Effects of extrusion and traditional processing methods on antinutrients and in vitro digestibility of protein and starch in faba and kidney beans. Food Chemistry, 68(2), 159-165. https://doi.org/10.1016/ S0308-8146(99)00169-7

Añón, M. C., de Lamballerie, M., \& Speroni, F. (2011). Influence of $\mathrm{NaCl}$ concentration and high pressure treatment on thermal denaturation of soybean proteins. Innovative Food Science \& Emerging Technologies, 12(4), 443-450. https://doi.org/10.1016/j. ifset.2011.06.010

Arribas, C., Cabellos, B., Sánchez, C., Cuadrado, C., Guillamón, E., \& Pedrosa, M. M. (2017). The impact of extrusion on the nutritional composition, dietary fiber and in vitro digestibility of gluten-free snacks based on rice, pea and carob flour blends. Food \& Function, 8(10), 3654-3663. https://doi.org/10.1039/c7fo00910k

Aryee, A. N. A., Agyei, D., \& Udenigwe, C. C. (2018). 2 - impact of processing on the chemistry and functionality of food proteins. In R. Y. B. T.-P., \& F. P. (Second E. Yada (Eds.), Woodhead publishing series in food science, technology and nutrition (pp. 27-45). Woodhead Publishing. https://doi.org/10.1016/B978-0-08-100722-8.00003-6.

Aryee, A. N. A., \& Boye, J. I. (2017). Comparative study of the effects of processing on the nutritional, physicochemical and functional properties of lentil. Journal of Food Processing and Preservation, 41(1), Article e12824. https://doi.org/10.1111/ jfpp. 12824

Baier, A. K., \& Knorr, D. (2015). Influence of high isostatic pressure on structural and functional characteristics of potato protein. Food Research International, 77, 753-761. https://doi.org/10.1016/j.foodres.2015.05.053

Balasubramaniam, V. M., Farkas, D., \& Turek, E. J. (2008). Preserving foods through high-pressure processing. Food Technology, 62(11), 32-38.

Balasubramaniam, V. M. B., Martínez-Monteagudo, S. I., \& Gupta, R. (2015). Principles and application of high pressure-based technologies in the food industry. Annual Review of Food Science and Technology, 6, 435-462. https://doi.org/10.1146/ annurev-food-022814-015539

Berghout, J. A. M., Boom, R. M., \& van der Goot, A. J. (2015). Understanding the differences in gelling properties between lupin protein isolate and soy protein isolate. Food Hydrocolloids, 43, 465-472. https://doi.org/10.1016/j. foodhyd.2014.07.003

Bessada, S. M. F., Barreira, J. C. M., \& Oliveira, M. B. P. P. (2019). Pulses and food security: Dietary protein, digestibility, bioactive and functional properties. Trends in Food Science \& Technology, 93, 53-68. https://doi.org/10.1016/j.tifs.2019.08.022

Boye, J. I., Aksay, S., Roufik, S., Ribéreau, S., Mondor, M., Farnworth, E., et al. (2010). Comparison of the functional properties of pea, chickpea and lentil protein concentrates processed using ultrafiltration and isoelectric precipitation techniques. Food Research International, 43(2), 537-546. https://doi.org/10.1016/j. foodres.2009.07.021

Boye, J., Zare, F., \& Pletch, A. (2010). Pulse proteins: Processing, characterization, functional properties and applications in food and feed. Food Research International, 43(2), 414-431. https://doi.org/10.1016/j.foodres.2009.09.003

Burger, T. G., \& Zhang, Y. (2019). Recent progress in the utilization of pea protein as an emulsifier for food applications. Trends in Food Science \& Technology, 86, 25-33. https://doi.org/10.1016/j.tifs.2019.02.007

Burgos-Díaz, C., Gallardo, M., Morales, E., Piornos, J. A., Marqués, A. M., \& Rubilar, M. (2016). Utilization of proteins from AluProt-CGNA (a novel protein-rich lupin variety) in the development of oil-in-water multilayer emulsion systems. European Journal of Lipid Science and Technology, 118(7), 1104-1112. https://doi.org/ 10.1002/ejlt.201500260

Cha, Y.-H. (2011). Effect of ohmic heating on characteristics of heating denaturation of soybean protein. The Korean Journal of Food And Nutrition, 24(4), 740-745. https:// doi.org/10.9799/KSFAN.2011.24.4.740

Chalamaiah, M., Yu, W., \& Wu, J. (2018). Immunomodulatory and anticancer protein hydrolysates (peptides) from food proteins: A review. Food Chemistry, 245, 205-222. https://doi.org/10.1016/j.foodchem.2017.10.087

Chao, D., Jung, S., \& Aluko, R. E. (2018). Physicochemical and functional properties of high pressure-treated isolated pea protein. Innovative Food Science \& Emerging Technologies, 45, 179-185. https://doi.org/10.1016/j.ifset.2017.10.014

Chen, G., Wang, S., Feng, B., Jiang, B., \& Miao, M. (2019). Interaction between soybean protein and tea polyphenols under high pressure. Food Chemistry, 277, 632-638. https://doi.org/10.1016/j.foodchem.2018.11.024

Chu, L., Yang, L., Li, J., Lin, L., \& Zheng, G. (2019). Effect of Smilax China L. starch on the gel properties and interactions of calcium sulfate-induced soy protein isolate gel. International Journal of Biological Macromolecules, 135, 127-132. https://doi.org/ 10.1016/j.ijbiomac. 2019.05.130

Coda, R., Varis, J., Verni, M., Rizzello, C. G., \& Katina, K. (2017). Improvement of the protein quality of wheat bread through faba bean sourdough addition. LebensmittelWissenschaft und -Technologie- Food Science and Technology, 82, 296-302. https://doi. org/10.1016/j.lwt.2017.04.062

Condés, M. C., Añón, M. C., \& Mauri, A. N. (2015). Amaranth protein films prepared with high-pressure treated proteins. Journal of Food Engineering, 166, 38-44. https://doi. org/10.1016/j.jfoodeng.2015.05.005

Considine, K. M., Kelly, A. L., Fitzgerald, G. F., Hill, C., \& Sleator, R. D. (2008). Highpressure processing - effects on microbial food safety and food quality. FEMS Microbiology Letters, 281(1), 1-9. https://doi.org/10.1111/j.1574-6968.2008.01084.

Dakhili, S., Abdolalizadeh, L., Hosseini, S. M., Shojaee-Aliabadi, S., \& Mirmoghtadaie, L. (2019). Quinoa protein: Composition, structure and functional properties. Food Chemistry, 299, Article 125161. https://doi.org/10.1016/j.foodchem.2019.125161

Daliri, E. B.-M., Oh, D. H., \& Lee, B. H. (2017). Bioactive peptides. Foods, 6(5), 1-21. https://doi.org/10.3390/foods6050032

Damodaran, S. (2005). Protein stabilization of emulsions and foams. Journal of Food Science, 70(3), R54-R66. https://doi.org/10.1111/j.1365-2621.2005.tb07150.x

Day, L. (2013). Proteins from land plants - potential resources for human nutrition and food security. Trends in Food Science \& Technology, 32(1), 25-42. https://doi.org/ 10.1016/j.tifs. 2013.05.005

De Maria, S., Ferrari, G., \& Maresca, P. (2016). Effects of high hydrostatic pressure on the conformational structure and the functional properties of bovine serum albumin. Innovative Food Science \& Emerging Technologies, 33, 67-75. https://doi.org/10.1016/ j.ifset.2015.11.025

De Vries, H., Mikolajczak, M., Salmon, J.-M., Abecassis, J., Chaunier, L., Guessasma, S., et al. (2018). Small-scale food process engineering — challenges and perspectives. 
Innovative Food Science \& Emerging Technologies, 46, 122-130. https://doi.org/ 10.1016/j.ifset.2017.09.009

Drulyte, D., \& Orlien, V. (2019). The effect of processing on digestion of legume proteins Foods, 8(6), 224. https://doi.org/10.3390/foods8060224

Elsohaimy, S. A., Refaay, T. M., \& Zaytoun, M. A. M. (2015). Physicochemical and functional properties of quinoa protein isolate. Annals of Agricultural Science, 60(2), 297-305. https://doi.org/10.1016/j.aoas.2015.10.007

Espinosa-Páez, E., Alanis-Guzmán, M. G., Hernández-Luna, C. E., Báez-González, J. G., Amaya-Guerra, C. A., \& Andrés-Grau, A. M. (2017). Increasing antioxidant activity and protein digestibility in Phaseolus vulgaris and avena sativa by fermentation with the pleurotus ostreatus fungus. Molecules, 22(12). https://doi.org/10.3390/ molecules 22122275

Evangelho, J. A. do, Vanier, N. L., Pinto, V. Z., Berrios, J. J. De, Dias, A. R. G., \& Zavareze, E. da R. (2017). Black bean (Phaseolus vulgaris L.) protein hydrolysates: Physicochemical and functional properties. Food Chemistry, 214, 460-467. https:// doi.org/10.1016/j.foodchem.2016.07.046

Fabian, C., \& Ju, Y.-H. (2011). A review on rice bran protein: Its properties and extraction methods. Critical Reviews in Food Science and Nutrition, 51(9), 816-827. https://doi.org/10.1080/10408398.2010.482678

Fasolin, L. H., Pereira, R. N., Pinheiro, A. C., Martins, J. T., Andrade, C. C. P., Ramos, O. L., et al. (2019). Emergent food proteins - towards sustainability, health and innovation. Food Research International, 125, Article 108586. https://doi.org/ 10.1016/j.foodres.2019.108586

Franck, M., Perreault, V., Suwal, S., Marciniak, A., Bazinet, L., \& Doyen, A. (2019). High hydrostatic pressure-assisted enzymatic hydrolysis improved protein digestion of flaxseed protein isolate and generation of peptides with antioxidant activity. Food Research International, 115, 467-473. https://doi.org/10.1016/j. foodres.2018.10.034

Galazka, V. B., Dickinson, E., \& Ledward, D. A. (1999). Emulsifying behaviour of 11S globulin Vicia faba in mixtures with sulphated polysaccharides: Comparison of thermal and high-pressure treatments. Food Hydrocolloids, 13(5), 425-435. https:// doi.org/10.1016/S0268-005X(99)00028-4

Galazka, V. B., Dickinson, E., \& Ledward, D. A. (2000). Influence of high pressure on interactions of $11 \mathrm{~S}$ globulin Vicia faba with 1-carrageenan in bulk solution and at interfaces. Food Hydrocolloids, 14(6), 551-560. https://doi.org/10.1016/S0268005X(00)00035-7

Galazka, V. B., Dickinson, E., \& Ledward, D. (2000). Effect of high-pressure on surface behaviour of adsorbed films formed from mixtures of sulfated polysaccharides with various proteins. Innovative Food Science \& Emerging Technologies, 1(3), 177-185. https://doi.org/10.1016/S1466-8564(00)00035-7

Gharibzahedi, S. M. T., \& Smith, B. (2021). Effects of high hydrostatic pressure on the quality and functionality of protein isolates, concentrates, and hydrolysates derived from pulse legumes: A review. Trends in Food Science \& Technology, 107, 466-479. https://doi.org/10.1016/j.tifs.2020.11.016

Giami, S. Y. (2004). Effect of fermentation on the seed proteins, nitrogenous constituents, antinutrients and nutritional quality of fluted pumpkin (Telfairia occidentalis Hook) Food Chemistry, 88(3), 397-404. https://doi.org/10.1016/j.foodchem.2004.01.064

Han, Z., Cai, M., Cheng, J.-H., \& Sun, D.-W. (2018). Effects of electric fields and electromagnetic wave on food protein structure and functionality: A review. Trends in Food Science \& Technology, 75, 1-9. https://doi.org/10.1016/j.tifs.2018.02.017

He, R., He, H.-Y., Chao, D., Ju, X., \& Aluko, R. (2014). Effects of high pressure and heat treatments on physicochemical and gelation properties of rapeseed protein isolate. Food and Bioprocess Technology, 7(5), 1344-1353. https://doi.org/10.1007/s11947 013-1139-z

Hernández-Ledesma, B., García-Nebot, M. J., Fernández-Tomé, S., Amigo, L., \& Recio, I. (2014). Dairy protein hydrolysates: Peptides for health benefits. International Dairy Journal, 38(2), 82-100. https://doi.org/10.1016/j.idairyj.2013.11.004

Hoogenkamp, H., Kumagai, H., Wanasundara, J. P. D., \& L. B. T.-S. P. S. Scanlin. (2017) Chapter 3 - rice protein and rice protein products. In S. R. Nadathur, \& J. P. D. Wanasundara (Eds.), Sustainable protein sources (pp. 47-65). Academic Press. https://doi.org/10.1016/B978-0-12-802778-3.00003-2.

Huang, H.-W., Wu, S.-J., Lu, J.-K., Shyu, Y.-T., \& Wang, C.-Y. (2017). Current status and future trends of high-pressure processing in food industry. Food Control, 72, 1-8. https://doi.org/10.1016/j.foodcont.2016.07.019

Huppertz, T., Vasiljevic, T., Zisu, B., \& Deeth, H. (2019). Chapter 8 - novel processing technologies: Effects on whey protein structure and functionality. In H. C. Deeth, \& N. B. T.-W. P. Bansal (Eds.), Whey proteins: From milk to medicine (pp. 281-334). Academic Press. https://doi.org/10.1016/B978-0-12-812124-5.00009-6.

Jaeger, H., Roth, A., Toepfl, S., Holzhauser, T., Engel, K.-H., Knorr, D., et al. (2016). Opinion on the use of ohmic heating for the treatment of foods. Trends in Food Science \& Technology, 55, 84-97. https://doi.org/10.1016/j.tifs.2016.07.007

James Harper, W., \& A. B. T.-M. P. (S.econd E. Thompson. (2014). Chapter 15 - model food systems and protein functionality. In H. Singh, \& M. Boland (Eds.), Food science and technology (pp. 451-472). Academic Press. https://doi.org/10.1016/B978-0-12 405171-3.00015-5.

Jin, B., Zhou, X., Zhong, Y., Li, Q., Zhang, S., Mo, H., et al. (2021). The synergistic effect of high pressure processing and pectin on the physicochemical stability and antioxidant properties of biopolymer complexes composed of soy protein and coumarin. Process Biochemistry. https://doi.org/10.1016/j.procbio.2021.03.001.

Joshi, M., Adhikari, B., Aldred, P., Panozzo, J. F., \& Kasapis, S. (2011). Physicochemical and functional properties of lentil protein isolates prepared by different drying methods. Food Chemistry, 129(4), 1513-1522. https://doi.org/10.1016/j. foodchem.2011.05.131

Kadam, D., Palamthodi, S., \& Lele, S. S. (2019). Complexation of curcumin with Lepidium sativum protein hydrolysate as a novel curcumin delivery system. Food Chemistry, 298, Article 125091. https://doi.org/10.1016/j.foodchem.2019.125091
Karaca, A. C., Low, N., \& Nickerson, M. (2011). Emulsifying properties of chickpea, faba bean, lentil and pea proteins produced by isoelectric precipitation and salt extraction. Food Research International, 44(9), 2742-2750. https://doi.org/10.1016/ j.foodres.2011.06.012

Khan, N. M., Mu, T.-H., Ali, F., Arogundade, L. A., Khan, Z. U., Zhang, M., et al. (2015). Effects of high hydrostatic pressure on emulsifying properties of sweet potato protein in model protein-hydrocolloids system. Food Chemistry, 169, 448-454. https://doi. org/10.1016/j.foodchem.2014.08.013

Khan, N. M., Mu, T.-H., Sun, H.-N., Zhang, M., \& Chen, J.-W. (2015). Effects of high hydrostatic pressure on secondary structure and emulsifying behavior of sweet potato protein. High Pressure Research, 35(2), 189-202. https://doi.org/10.1080/ 08957959.2015.1005013

Kim, J. H. J., Varankovich, N. V., \& Nickerson, M. T. (2016). The effect of pH on the gelling behaviour of canola and soy protein isolates. Food Research International, 81, 31-38. https://doi.org/10.1016/j.foodres.2015.12.029

Knirsch, M. C., Alves dos Santos, C., Martins de Oliveira Soares Vicente, A. A., \& Vessoni Penna, T. C. (2010). Ohmic heating - a review. Trends in Food Science \& Technology, 21(9), 436-441. https://doi.org/10.1016/j.tifs.2010.06.003

Knorr, D., Heinz, V., \& Buckow, R. (2006). High pressure application for food biopolymers. Biochimica et Biophysica Acta (BBA) - Proteins \& Proteomics, 1764(3), 619-631. https://doi.org/10.1016/j.bbapap.2006.01.017

Koeberl, M., Clarke, D., \& Lopata, A. L. (2014). Next generation of food allergen quantification using mass spectrometric systems. Journal of Proteome Research, 13(8), 3499-3509. https://doi.org/10.1021/pr500247r

Kumar, S. (2016). Meat Analogs "Plant based alternatives to meat products: Thei production technology and applications. Critical Reviews in Food Science and Nutrition. https://doi.org/10.1080/10408398.2016.1196162

Kumar, T. (2018). A review on ohmic heating technology: Principle, applications and scope. International Journal of Agriculture Environment \& Biotechnology, 11(4), 679-687. https://doi.org/10.30954/0974-1712.08.2018.10

Kyriakopoulou, K., Dekkers, B., \& van der Goot, A. J. (2019). Chapter 6 - plant-based meat analogues. In C. M. B. T. S. M. P., \& P. Galanakis (Eds.), Sustainable meat production and processing (pp. 103-126). Academic Press. https://doi.org/10.1016/ B978-0-12-814874-7.00006-7.

Lafarga, T. (2018). Potential applications of plant-derived proteins in the food industry. In Novel proteins for food, pharmaceuticals and agriculture (pp. 117-137). https://doi. org $/ 10.1002 / 9781119385332 . c h 6$

Laguna, L., Picouet, P., Guàrdia, M. D., Renard, C. M. G. C., \& Sarkar, A. (2017). In vitro gastrointestinal digestion of pea protein isolate as a function of $\mathrm{pH}$, food matrices, autoclaving, high-pressure and re-heat treatments. LWT, 84, 511-519. https://doi. org/10.1016/j.lwt.2017.06.021

Lee, H., Ha, M. J., Shahbaz, H. M., Kim, J. U., Jang, H., \& Park, J. (2018). High hydrostatic pressure treatment for manufacturing of red bean powder: A comparison with the thermal treatment. Journal of Food Engineering, 238, 141-147. https://doi. org/10.1016/j.jfoodeng.2018.06.016

Lei, L., Zhi, H., Xiujin, Z., Takasuke, I., \& Zaigui, L. (2007). Effects of different heating methods on the production of protein-lipid film. Journal of Food Engineering, 82(3), 292-297. https://doi.org/10.1016/j.jfoodeng.2007.02.030

Lin, D., Lu, W., Kelly, A. L., Zhang, L., Zheng, B., \& Miao, S. (2017). Interactions of vegetable proteins with other polymers: Structure-function relationships and applications in the food industry. Trends in Food Science \& Technology, 68, 130-144. https://doi.org/10.1016/j.tifs.2017.08.006

Linsberger-Martin, G., Weiglhofer, K., Thi Phuong, T. P., \& Berghofer, E. (2013). High hydrostatic pressure influences antinutritional factors and in vitro protein digestibility of split peas and whole white beans. Lebensmittel-Wissenschaft und -Technologie- Food Science and Technology, 51(1), 331-336. https://doi.org/10.1016/ j.lwt.2012.11.008

Liu, X., Huang, Y.-Q., Chen, X.-W., Deng, Z.-Y., \& Yang, X.-Q. (2019). Whole cereal protein-based Pickering emulsions prepared by zein-gliadin complex particles. Journal of Cereal Science, 87, 46-51. https://doi.org/10.1016/j.jcs.2019.02.004

Liu, D., Zhang, L., Wang, Y., Li, Z., Wang, Z., \& Han, J. (2020). Effect of high hydrostatic pressure on solubility and conformation changes of soybean protein isolate glycated with flaxseed gum. Food Chemistry, 333, Article 127530. https://doi.org/10.1016/j. foodchem.2020.127530

Li, J., Wu, M., Wang, Y., Li, K., Du, J., \& Bai, Y. (2020). Effect of pH-shifting treatment on structural and heat induced gel properties of peanut protein isolate. Food Chemistry, 325, Article 126921. https://doi.org/10.1016/j.foodchem.2020.126921

Li, X., Ye, C., Tian, Y., Pan, S., \& Wang, L. (2018). Effect of ohmic heating on fundamental properties of protein in soybean milk. Journal of Food Process Engineering, 41(3), Article e12660. https://doi.org/10.1111/jfpe.12660

Li, H., Zhu, K., Zhou, H., \& Peng, W. (2011). Effects of high hydrostatic pressure on some functional and nutritional properties of soy protein isolate for infant formula. Journal of Agricultural and Food Chemistry, 59(22), 12028-12036. https://doi.org/10.1021/ jf203390e

López-Fandiño, R. (2006). Functional improvement of milk whey proteins induced by high hydrostatic pressure. Critical Reviews in Food Science and Nutrition, 46(4), 351-363. https://doi.org/10.1080/10408690590957278

López, D. N., Galante, M., Raimundo, G., Spelzini, D., \& Boeris, V. (2019). Functional properties of amaranth, quinoa and chia proteins and the biological activities of their hydrolyzates. Food Research International, 116, 419-429. https://doi.org/10.1016/j. foodres.2018.08.056

López, D. N., Ingrassia, R., Busti, P., Wagner, J., Boeris, V., \& Spelzini, D. (2018). Effects of extraction $\mathrm{pH}$ of chia protein isolates on functional properties. LWT, 97, 523-529. https://doi.org/10.1016/j.lwt.2018.07.036 
Loveday, S. M. (2019). Food proteins: Technological, nutritional, and sustainability attributes of traditional and emerging proteins. Annual Review of Food Science and Technology, 10(1), 311-339. https://doi.org/10.1146/annurev-food-032818-121128

Ma, F., Chen, C., Zheng, L., Zhou, C., Cai, K., \& Han, Z. (2013). Effect of high pressure processing on the gel properties of salt-soluble meat protein containing $\mathrm{CaCl} 2$ and к-carrageenan. Meat Science, 95(1), 22-26. https://doi.org/10.1016/j. meatsci.2013.04.025

Messens, W., Van Camp, J., \& Huyghebaert, A. (1997). The use of high pressure to modify the functionality of food proteins. Trends in Food Science \& Technology, 8(4), 107-112. https://doi.org/10.1016/S0924-2244(97)01015-7

Mokni Ghribi, A., Maklouf Gafsi, I., Sila, A., Blecker, C., Danthine, S., Attia, H., et al. (2015). Effects of enzymatic hydrolysis on conformational and functional propertie of chickpea protein isolate. Food Chemistry, 187, 322-330. https://doi.org/10.1016/ j.foodchem.2015.04.109

Moreno-Valdespino, C. A., Luna-Vital, D., Camacho-Ruiz, R. M., \& Mojica, L. (2020). Bioactive proteins and phytochemicals from legumes: Mechanisms of action preventing obesity and type-2 diabetes. Food Research International, 130, Article 108905. https://doi.org/10.1016/j.foodres.2019.108905. February 2019.

Munir, M., Nadeem, M., Qureshi, T. M., Leong, T. S. H., Gamlath, C. J., Martin, G. J. O., et al. (2019). Effects of high pressure, microwave and ultrasound processing on proteins and enzyme activity in dairy systems - a review. Innovative Food Science \& Emerging Technologies, 57, Article 102192. https://doi.org/10.1016/j. ifset.2019.102192

Muntean, M.-V., Marian, O., Barbieru, V., Cătunescu, G. M., Ranta, O., Drocas, I., et al. (2016). High pressure processing in food industry - characteristics and applications. Agriculture and Agricultural Science Procedia, 10, 377-383. https://doi.org/10.1016/j. aaspro.2016.09.077

Neacsu, M., McBey, D., Johnstone, A. M., \& L. B. T.-S. P. S. Scanlin. (2017). Chapter 22 meat reduction and plant-based food: Replacement of meat: Nutritional, health, and social aspects. In S. R. Nadathur, \& J. P. D. Wanasundara (Eds.), Sustainable protein sources (pp. 359-375). Academic Press. https://doi.org/10.1016/B978-0-12802778-3.00022-6.

Nicolai, T., \& Chassenieux, C. (2019). Heat-induced gelation of plant globulins. Current Opinion in Food Science, 27, 18-22. https://doi.org/10.1016/j.cofs.2019.04.005

Nieto Nieto, T. V., Wang, Y., Ozimek, L., \& Chen, L. (2016). Improved thermal gelation of oat protein with the formation of controlled phase-separated networks using dextrin and carrageenan polysaccharides. Food Research International, 82, 95-103. https:// doi.org/10.1016/j.foodres.2016.01.027

van de Noort, M., \& L. B. T.-S. P. S. Scanlin. (2017). Chapter 10 - lupin: An important protein and nutrient source. In S. R. Nadathur, \& J. P. D. Wanasundara (Eds.), Sustainable protein sources (pp. 165-183). Academic Press. https://doi.org/10.1016/ B978-0-12-802778-3.00010-X.

Orlien, V., Olsen, K., \& Skibsted, L. H. (2007). In situ measurements of pH changes in $\beta$-lactoglobulin solutions under high hydrostatic pressure. Journal of Agricultural and Food Chemistry, 55(11), 4422-4428. https://doi.org/10.1021/jf062840o

Osborne, T. B. (1908). Our present knowledge of plant proteins. Science, 28(718), 417-427. http://www.jstor.org/stable/1634598.

Pedrosa, C., \& Ferreira, S. T. (1994). Deterministic pressure-induced dissociation of vicilin, the 7S storage globulin from pea seeds: Effects of $\mathrm{pH}$ and cosolvents on oligomer stability. Biochemistry, 33(13), 4046-4055. https://doi.org/10.1021/ bi00179a033

Pencharz, P. B., Elango, R., \& Wolfe, R. R. (2016). Recent developments in understanding protein needs - how much and what kind should we eat? Applied Physiology, Nutrition, and Metabolism = Physiologie Appliquee, Nutrition et Metabolisme, 41(5), 577-580. https://doi.org/10.1139/apnm-2015-0549

Pereira, R. N., Teixeira, J. A., \& Vicente, A. A. (2011). Exploring the denaturation of whey proteins upon application of moderate electric fields: A kinetic and thermodynamic study. Journal of Agricultural and Food Chemistry, 59(21), 11589-11597. https://doi.org/10.1021/jf201727s

Pereira, R., Teixeira, J. A., Vicente, A. A., Cappato, L. P., da Silva Ferreira, M. V., da Silva Rocha, R., et al. (2018). Ohmic heating for the dairy industry: A potential technology to develop probiotic dairy foods in association with modifications of whey protein structure. Current Opinion in Food Science, 22, 95-101. https://doi.org/10.1016/j. cofs.2018.01.014

Pereira, R. N., \& Vicente, A. A. (2010). Environmental impact of novel thermal and nonthermal technologies in food processing. Food Research International, 43(7), 1936-1943. https://doi.org/10.1016/j.foodres.2009.09.013

Peyrano, F., de Lamballerie, M., Avanza, M. V., \& Speroni, F. (2019). Rheological characterization of the thermal gelation of cowpea protein isolates: Effect of pretreatments with high hydrostatic pressure or calcium addition. LWT, 115, Article 108472. https://doi.org/10.1016/j.lwt.2019.108472

Peyrano, F., de Lamballerie, M., Speroni, F., \& Avanza, M. V. (2019). Rheological characterization of thermal gelation of cowpea protein isolates: Effect of processing conditions. LWT, 109, 406-414. https://doi.org/10.1016/j.lwt.2019.04.048

Pham, L. B., Wang, B., Zisu, B., \& Adhikari, B. (2019). Complexation between flaxseed protein isolate and phenolic compounds: Effects on interfacial, emulsifying and antioxidant properties of emulsions. Food Hydrocolloids, 94, 20-29. https://doi.org/ 10.1016/j.foodhyd.2019.03.007

Pojić, M., Mišan, A., \& Tiwari, B. (2018). Eco-innovative technologies for extraction of proteins for human consumption from renewable protein sources of plant origin. Trends in Food Science \& Technology, 75, 93-104. https://doi.org/10.1016/j. tifs. 2018.03.010

Poore, J., \& Nemecek, T. (2018). Reducing food's environmental impacts through producers and consumers. Science (New York, N.Y.), 360(6392), 987-992. https:// doi.org/10.1126/science.aaq0216
Porras Saavedra, J., Güémes-Vera, N., Soto, J. L., Martínez, M., \& Yañez, J. (2013). Comparative study of functional properties of protein isolates obtained from three Lupinus species. Advances in Bio Research, 4(4), 106-116.

Qin, Z., Guo, X., Lin, Y., Chen, J., Liao, X., Hu, X., et al. (2013). Effects of high hydrostatic pressure on physicochemical and functional properties of walnut (Juglans regia L.) protein isolate. Journal of the Science of Food and Agriculture, 93(5), 1105-1111. https://doi.org/10.1002/jsfa.5857

Queirós, R. P., Saraiva, J. A., \& da Silva, J. A. L. (2018). Tailoring structure and technological properties of plant proteins using high hydrostatic pressure. Critical Reviews in Food Science and Nutrition, 58(9), 1538-1556. https://doi.org/10.1080/ 10408398.2016.1271770

Rahmati, N. F., Koocheki, A., Varidi, M., \& Kadkhodaee, R. (2018). Introducing Speckled sugar bean (Phaseolus vulgaris) protein isolates as a new source of emulsifying agent. Food Hydrocolloids, 79, 498-508. https://doi.org/10.1016/j. foodhyd.2018.01.022

Ramos, O., Pereira, R., Martins, A., Rodrigues, R. M., Fuciños, C., Teixeira, J., et al. (2015). Design of whey protein nanostructures for incorporation and release of nutraceutical compounds in food. Critical Reviews in Food Science and Nutrition, 57, 1377-1393. https://doi.org/10.1080/10408398.2014.993749

Rendueles, E., Omer, M. K., Alvseike, O., Alonso-Calleja, C., Capita, R., \& Prieto, M. (2011). Microbiological food safety assessment of high hydrostatic pressure processing: A review. Lebensmittel-Wissenschaft und -Technologie- Food Science and Technology, 44(5), 1251-1260. https://doi.org/10.1016/j.lwt.2010.11.001

Ribnicky, D. M., Roopchand, D. E., Poulev, A., Kuhn, P., Oren, A., Cefalu, W. T., et al. (2014). Artemisia dracunculus L. polyphenols complexed to soy protein show enhanced bioavailability and hypoglycemic activity in C57BL/6 mice. Nutrition, 30 (7), S4-S10. https://doi.org/10.1016/j.nut.2014.03.009

Rodrigues, R. M., Avelar, Z., Vicente, A. A., Petersen, S. B., \& Pereira, R. N. (2020). Influence of moderate electric fields in $\beta$-lactoglobulin thermal unfolding and interactions. Food Chemistry, 304, Article 125442. https://doi.org/10.1016/j. foodchem.2019.125442

Rodrigues, R. M., Fasolin, L. H., Avelar, Z., Petersen, S. B., Vicente, A. A., \& Pereira, R. N. (2020). Effects of moderate electric fields on cold-set gelation of whey proteins from molecular interactions to functional properties. Food Hydrocolloids, 101, Article 105505. https://doi.org/10.1016/j.foodhyd.2019.105505

Rodrigues, R. M., Genisheva, Z., Rocha, C. M. R., Teixeira, J. A., Vicente, A. A., Pereira, R. N., \& E. B. T.-G. F. P. T. Vorobiev. (2019). 6 - ohmic heating for preservation, transformation, and extraction. In F. Chemat (Ed.), Green food processing techniques- preservation, transformation and extraction (pp. 159-191) Academic Press. https://doi.org/10.1016/B978-0-12-815353-6.00006-9.

Rodrigues, R. M., Martins, A. J., Ramos, O. L., Malcata, F. X., Teixeira, J. A., Vicente, A. A., et al. (2015). Influence of moderate electric fields on gelation of whey protein isolate. Food Hydrocolloids, 43, 329-339. https://doi.org/10.1016/j. foodhyd.2014.06.002

Sakr, M., \& Liu, S. (2014). A comprehensive review on applications of ohmic heating $(\mathrm{OH})$. Renewable and Sustainable Energy Reviews, 39, 262-269. https://doi.org/ 10.1016/j.rser.2014.07.061

Sá, A. G. A., Moreno, Y. M. F., \& Carciofi, B. A. M. (2019). Food processing for the improvement of plant proteins digestibility. Critical Reviews in Food Science and Nutrition, 1-20. https://doi.org/10.1080/10408398.2019.1688249

Sastry, S. K. (2005). Advances in ohmic heating and moderate electric field (MFF) processing. In C. M. G. V. Barbosa-Canovas \&, \& M. S. Tapia (Eds.), Novel food processing technologies (pp. 491-499). CRC Press.

Sastry, S. (2008). Ohmic heating and moderate electric field processing. Food Science and Technology International, 14(5), 419-422. https://doi.org/10.1177/ 1082013208098813

Sastry, S. K., Jun, S., Somavat, R., Samaranayake, C., Yousef, A., \& Pandit, R. B. (2009). Heating and sterilization technology for long-duration space missions. Annals of the New York Academy of Sciences, 1161(1), 562-569. https://doi.org/10.1111/j.17496632.2009.04088.x

Shevkani, K., Kaur, A., Kumar, S., \& Singh, N. (2015). Cowpea protein isolates: Functional properties and application in gluten-free rice muffins. Lebensmittel Wissenschaft und -Technologie- Food Science and Technology, 63(2), 927-933. https:// doi.org/10.1016/j.lwt.2015.04.058

Shevkani, K., Singh, N., Chen, Y., Kaur, A., \& Yu, L. (2019). Pulse proteins: Secondary structure, functionality and applications. Journal of Food Science \& Technology, 56(6), 2787-2798. https://doi.org/10.1007/s13197-019-03723-8

Shevkani, K., Singh, N., Kaur, A., \& Rana, J. C. (2015). Structural and functional characterization of kidney bean and field pea protein isolates: A comparative study. Food Hydrocolloids, 43, 679-689. https://doi.org/10.1016/j.foodhyd.2014.07.024

Shimoyamada, M., Itabashi, Y., Sugimoto, I., Kanauchi, M., Ishida, M., Tsuzuki, K., et al. (2015). Characterization of soymilk prepared by ohmic heating and the effects of voltage applied. Food Science and Technology Research, 21(3), 439-444. https://doi. org/10.3136/fstr.21.439

Sieniawska, E., Maciejewska-Turska, M., Świątek, Ł., Xiao, J. (2020). Plant-based food products for antimycobacterial therapy. EFood, 1(3), 199-216. https://doi.org/ 10.2991/efood.k.200418.001

Silva, V. L. M., Santos, L. M. N. B. F., \& Silva, A. M. S. (2017). Ohmic heating: An emerging concept in organic synthesis. Chemistry - A European Journal, 23(33), 7853-7865. https://doi.org/10.1002/chem.201700307

Speroni, F., Añón, M. C., \& de Lamballerie, M. (2010). Effects of calcium and high pressure on soybean proteins: A calorimetric study. Food Research International, 43 (5), 1347-1355. https://doi.org/10.1016/j.foodres.2010.03.022

Sreerama, Y. N., Sashikala, V. B., Pratape, V. M., \& Singh, V. (2012). Nutrients and antinutrients in cowpea and horse gram flours in comparison to chickpea flour: 
Evaluation of their flour functionality. Food Chemistry, 131(2), 462-468. https://doi. org/10.1016/j.foodchem.2011.09.008

Stapelfeldt, H., \& Skibsted, L. H. (1999). Pressure denaturation and aggregation of betalactoglobulin studied by intrinsic fluorescence depolarization, Rayleigh scattering, radiationless energy transfer and hydrophobic fluoroprobing. Journal of Dairy Research, 66(4), 545-558. https://doi.org/10.1017/s0022029999003714

Stone, A. K., Nosworthy, M. G., Chiremba, C., House, J. D., \& Nickerson, M. T. (2019). A comparative study of the functionality and protein quality of a variety of legume and cereal flours. Cereal Chemistry, 96(6), 1159-1169. https://doi.org/10.1002/ cche. 10226

Subaşı, B. G., Jahromi, M., Casanova, F., Capanoglu, E., Ajalloueian, F., \& Mohammadifar, M. A. (2021). Effect of moderate electric field on structural and thermo-physical properties of sunflower protein and sodium caseinate. Innovative Food Science \& Emerging Technologies, 67, Article 102593. https://doi.org/10.1016/j. ifset.2020.102593

Tapal, A., \& Tiku, P. K. (2012). Complexation of curcumin with soy protein isolate and its implications on solubility and stability of curcumin. Food Chemistry, 130(4), 960-965. https://doi.org/10.1016/j.foodchem.2011.08.025

Tiwari, B. K., \& Singh, N. (2012). Pulse chemistry and technology. Royal Society of Chemistry. https://books.google.pt/books?id=ps8YYavx57EC.

Tuśnio, A., Taciak, M., Barszcz, M., Święch, E., Bachanek, I., \& Skomiał, J. (2017). Effect of replacing soybean meal by raw or extruded pea seeds on growth performance and selected physiological parameters of the ileum and distal colon of pigs. PloS One, 12 (1), Article e0169467. https://doi.org/10.1371/journal.pone.0169467

Udenigwe, C. C., \& Aluko, R. E. (2012). Food protein-derived bioactive peptides: Production, processing, and potential health benefits. Journal of Food Science, 77(1), R11-R24. https://doi.org/10.1111/j.1750-3841.2011.02455.X

Wang, M., Chen, X., Zou, Y., Chen, H., Xue, S., Qian, C., et al. (2017). High-pressure processing-induced conformational changes during heating affect water holding capacity of myosin gel. International Journal of Food Science and Technology, 52(3), 724-732. https://doi.org/10.1111/ijfs.13327

Wang, L.-J., Li, D., Tatsumi, E., Liu, Z.-S., Chen, X. D., \& Li, L.-T. (2007). Application of two-stage ohmic heating to tofu processing. Chemical Engineering and Processing: Process Intensification, 46(5), 486-490. https://doi.org/10.1016/j.cep.2006.06.017

Wang, B., Liu, F., Luo, S., Li, P., Mu, D., Zhao, Y., et al. (2019). Effects of high hydrostatic pressure on the properties of heat-induced wheat gluten gels. Food and Bioprocess Technology, 12(12), 220-227. https://doi.org/10.1007/s11947-018-2205-3

Winter, R., Lopes, D., Grudzielanek, S., \& Vogtt, K. (2007). Towards an understanding of the temperature/pressure configurational and free-energy landscape of biomolecules. Journal of Non-equilibrium Thermodynamics, 32(1), 41-97. https://doi. org/10.1515/JNETDY.2007.003

Wong, A., Pitts, K., Jayasena, V., \& Johnson, S. (2013). Isolation and foaming functionality of acid-soluble protein from lupin (Lupinus angustifolius) kernels. Journal of the Science of Food and Agriculture, 93(15), 3755-3762. https://doi.org/ $10.1002 / \mathrm{jsfa} .6249$

Worldometers. (2020). World population projections. https://www.worldometers.info/wo rld-population/world-population-projections/.

Wu, G., Fanzo, J., Miller, D. D., Pingali, P., Post, M., Steiner, J. L., et al. (2014). Production and supply of high-quality food protein for human consumption: Sustainability, challenges, and innovations. Annals of the New York Academy of Sciences, 1321, 1-19. https://doi.org/10.1111/nyas.12500
Xiang, H., Sun-waterhouse, D., Cui, C., Wang, W., \& Dong, K. (2018). Modification of soy protein isolate by glutaminase for nanocomplexation with curcumin. Food Chemistry, 268, 504-512. https://doi.org/10.1016/j.foodchem.2018.06.059

Yang, J. (2016). Effects of high pressure on food proteins. In Food engineering series (pp. 353-389). https://doi.org/10.1007/978-1-4939-3234-4 18

Yan, W., Yin, L., Li, J., Yadav, M. P., \& Jia, X. (2020). Development of corn fiber gum-soybean protein isolate double network hydrogels through synergistic gelation. Food and Bioprocess Technology, 13(3), 511-521. https://doi.org/10.1007/s11947020-02412-1

Yin, S.-W., Tang, C.-H., Wen, Q.-B., Yang, X.-Q., \& Li, L. (2008). Functional properties and in vitro trypsin digestibility of red kidney bean (Phaseolus vulgaris L.) protein isolate: Effect of high-pressure treatment. Food Chemistry, 110(4), 938-945. https:// doi.org/10.1016/j.foodchem.2008.02.090

Zhang, B., Liu, G., Ying, D., Sanguansri, L., \& Augustin, M. A. (2017). Effect of extrusion conditions on the physico-chemical properties and in vitro protein digestibility of canola meal. Food Research International, 100, 658-664. https://doi.org/10.1016/j. foodres.2017.07.060

Zhang, S. B., Wang, X. H., Li, X., \& Yan, D. Q. (2020). Effects of tween 20 and transglutaminase modifications on the functional properties of peanut proteins. Journal of the American Oil Chemists' Society, 97(1), 93-103. https://doi.org/ 10.1002/aocs.12309

Zhao, H., Chen, J., Hemar, Y., \& Cui, B. (2020). Improvement of the rheological and textural properties of calcium sulfate-induced soy protein isolate gels by the incorporation of different polysaccharides. Food Chemistry, 310, Article 125983. https://doi.org/10.1016/j.foodchem.2019.125983

Zhao, Z.-K., Mu, T.-H., Zhang, M., \& Richel, A. (2018a). Chemical forces, structure, and gelation properties of sweet potato protein as affected by $\mathrm{pH}$ and high hydrostatic pressure. Food and Bioprocess Technology, 11(9), 1719-1732. https://doi.org/ 10.1007/s11947-018-2137-y

Zhao, Z.-K., Mu, T.-H., Zhang, M., \& Richel, A. (2018b). Effect of salts combined with high hydrostatic pressure on structure and gelation properties of sweet potato protein. LWT, 93, 36-44. https://doi.org/10.1016/j.lwt.2018.03.007

Zhao, Z.-K., Mu, T.-H., Zhang, M., \& Richel, A. (2019). Effects of high hydrostatic pressure and microbial transglutaminase treatment on structure and gelation properties of sweet potato protein. LWT, 115, Article 108436. https://doi.org/ 10.1016/j.lwt.2019.108436

Zhao, H., Shen, C., Wu, Z., Zhang, Z., \& Xu, C. (2020). Comparison of wheat, soybean, rice, and pea protein properties for effective applications in food products. Journal of Food Biochemistry, 44(4), Article e13157. https://doi.org/10.1111/jfbc.13157

Zhao, J., Zhou, T., Zhang, Y., Ni, Y., \& Li, Q. (2015). Optimization of arachin extraction from defatted peanut (Arachis hypogaea) cakes and effects of ultra-high pressure (UHP) treatment on physiochemical properties of arachin. Food and Bioproducts Processing, 95, 38-46. https://doi.org/10.1016/j.fbp.2015.03.009

Zheng, Z., Li, J., \& Liu, Y. (2020). Effects of partial hydrolysis on the structural, functional and antioxidant properties of oat protein isolate. Food \& Function, 11(4), 3144-3155. https://doi.org/10.1039/C9FO01783F

Zhou, H., Wang, C., Ye, J., Chen, H., Tao, R., \& Cao, F. (2016). Effects of high hydrostatic pressure treatment on structural, allergenicity, and functional properties of proteins from ginkgo seeds. Innovative Food Science \& Emerging Technologies, 34, 187-195. https://doi.org/10.1016/j.ifset.2016.02.001 